Phenazine $N, N$ '-dioxide scaffold as selective hypoxic cytotoxin pharmacophore. Structural modifications looking for further DNA topoisomerase II-inhibition activity

Mariana Gonda, Marcos Nieves, Elia Nunes, Adela López de Ceráin, Antonio Monge, María Laura Lavaggi, Mercedes González and Hugo

Cerecetto

Figure S1

ESI-2

Table S1

ESI-3

Figure S2

ESI-4

Figure S3

ESI-5

Figure S4

ESI-6

Experimental details for the synthesis of benzofuroxan (IV)

ESI-7

Selected NMR spectra

ESI-8 

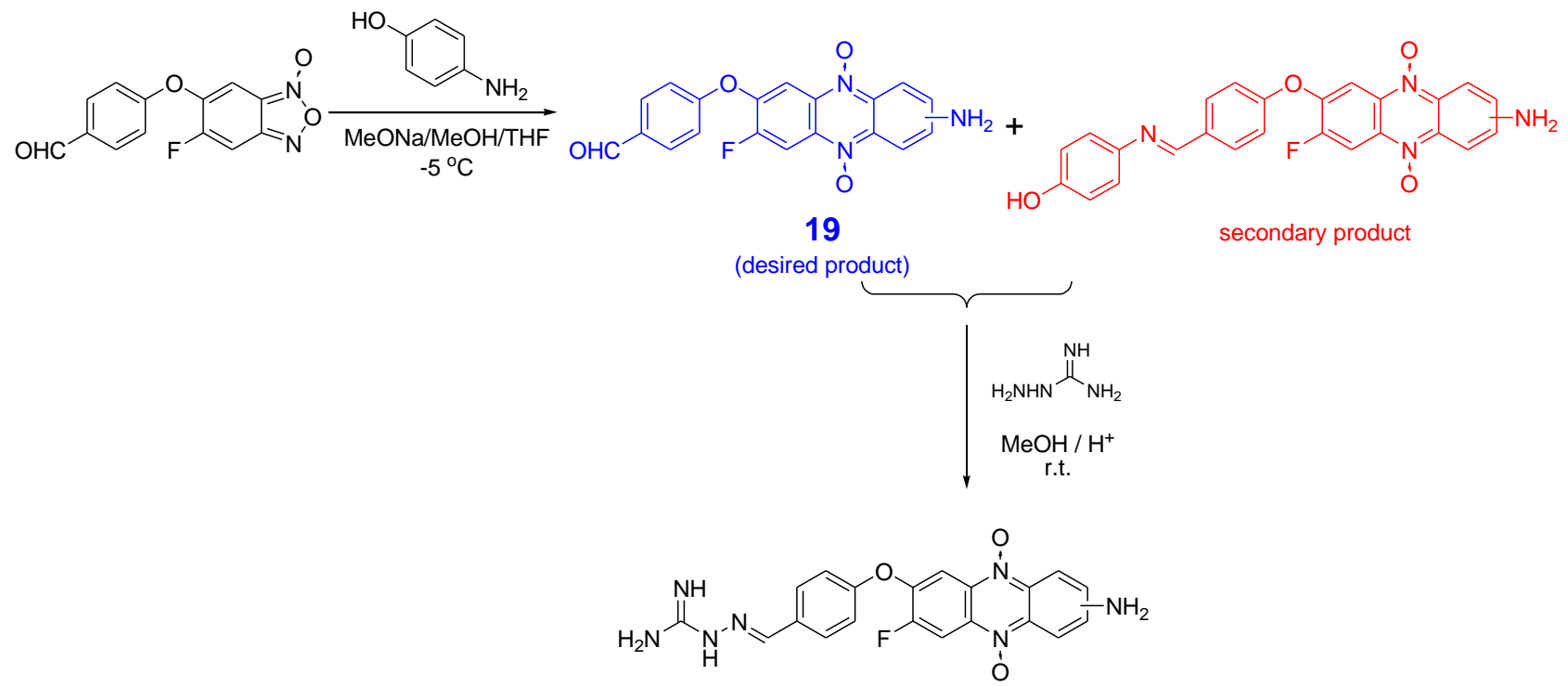

21

Figure S1. Synthetic scheme and results in the preparation of PDO 19. This compound was obtained mixed with the corresponding imine (secondary product). This mixture treated with aminoguanidine yield PDO 21. 
Table S1. Proportions of 7- and 8-Isomers of Studied Compounds.

\begin{tabular}{cc} 
compound & $\mathbf{7 : 8}$ isomers ratio \\
\hline $\mathbf{6}$ & $50: 50$ \\
$\mathbf{7}$ & $55: 45$ \\
$\mathbf{8}$ & $50: 50$ \\
$\mathbf{9}$ & $53: 47$ \\
$\mathbf{1 0}$ & $51: 49$ \\
$\mathbf{1 1}$ & $44: 56$ \\
$\mathbf{1 2}$ & $52: 48$ \\
$\mathbf{1 3}$ & $65: 35$ \\
$\mathbf{1 4}$ & $59: 41$ \\
$\mathbf{1 5}$ & $56: 44$ \\
$\mathbf{1 6}$ & $55: 45$ \\
$\mathbf{1 7}$ & $58: 42$ \\
$\mathbf{1 8}$ & $60: 40$ \\
& \\
$\mathbf{1 9}$ & $60: 40^{\mathrm{b}}$ \\
$\mathbf{2 0}$ & $65: 35^{\mathrm{b}}$ \\
$\mathbf{2 1}$ & $58: 42^{\mathrm{b}}$ \\
$\mathbf{2 2}$ & $60: 40^{\mathrm{b}}$ \\
$\mathbf{2 3}$ & $56: 44$ \\
$\mathbf{2 5}$ & $50: 50^{\mathrm{b}}$ \\
\hline
\end{tabular}

a Determined by ${ }^{1} \mathrm{H}-\mathrm{NMR}$ from the isolated products. ${ }^{\mathrm{b}}$ 7-fluoro- and 8fluoro-isomers. 


\section{Simulated hypoxia}

a)

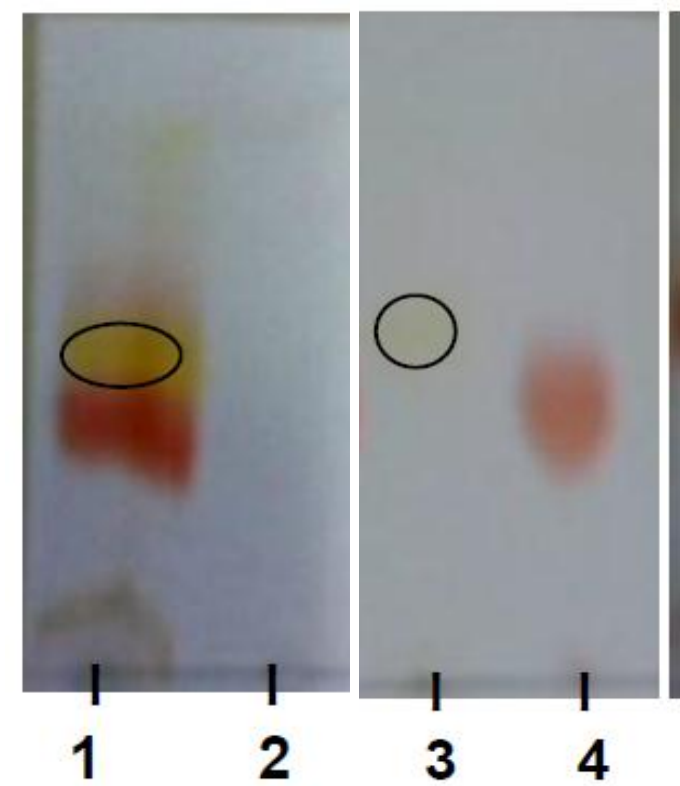

Simulated normoxia

c)

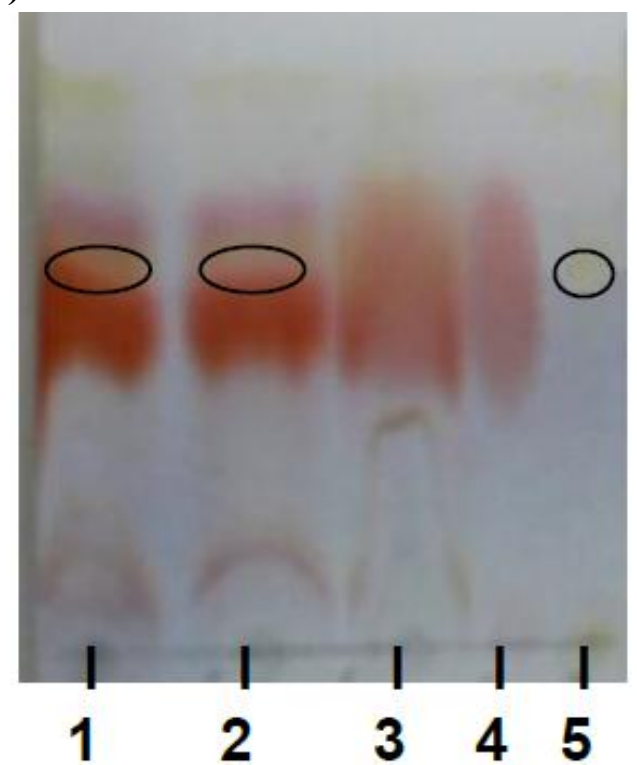

b)

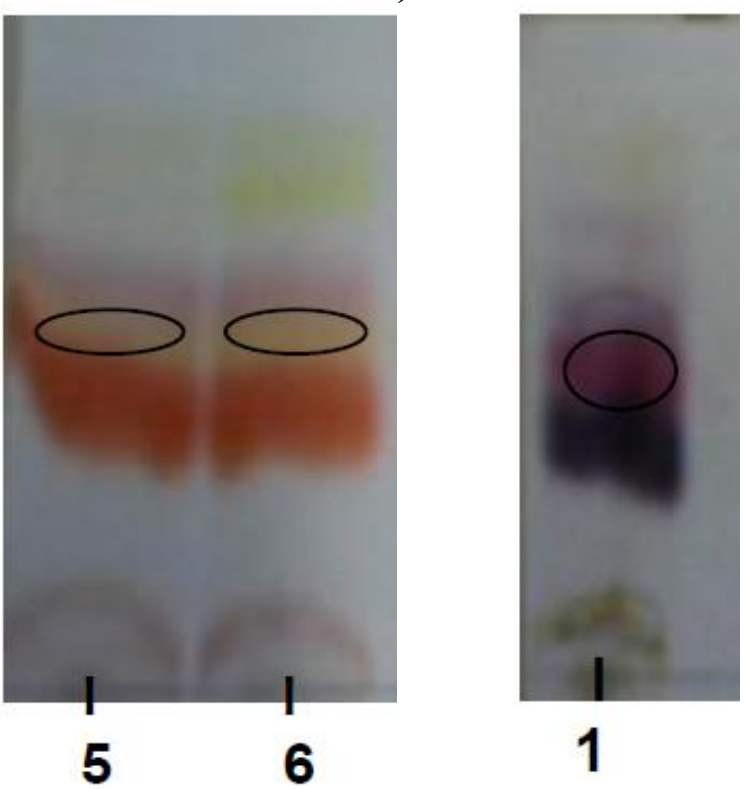

d)

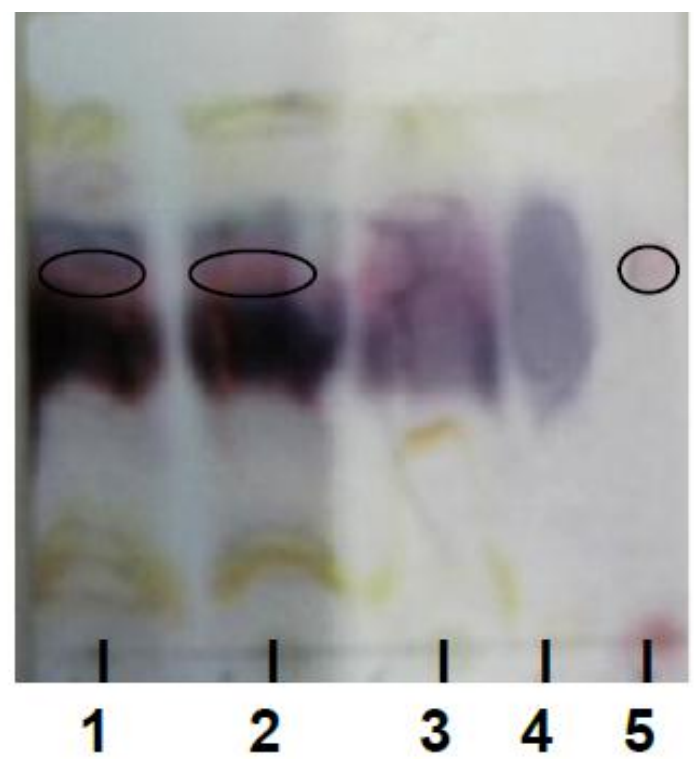

Figure S2. TLC chromatograms (see Material and methods for experimental conditions) taken after 30 min of incubation of PDO $\mathbf{1 2}$ with different protein fractions and in different gasification conditions. Simulated hypoxia: a) Spots without revealed (PDO, orange; phenazine monoxides, yellow); b) Run 1 spots visualised by spraying with a solution of $p$-anisaldehyde: $\mathrm{H}_{2} \mathrm{SO}_{4}(\mathrm{c})$ :EtOH (95:4:1) followed by heating. Runs: 1. Incubation with S9 fraction; 2. Control of enzymatic fractions; 3. PDO 23; 4. PDO 12; 5. Incubation with cytosolic fraction; 6. Incubation with microsomal fraction. Simulated normoxia: c) Spots without revealed (PDO, orange; phenazine monoxides, yellow); d) Spots visualised by spraying with a solution of $p$ anisaldehyde: $\mathrm{H}_{2} \mathrm{SO}_{4}(\mathrm{c})$ :EtOH (95:4:1) followed by heating. Runs: 1-3. Incubations with cytosolic, microsomal, and S9 fractions; 4. PDO 12; 5. PDO 23. 

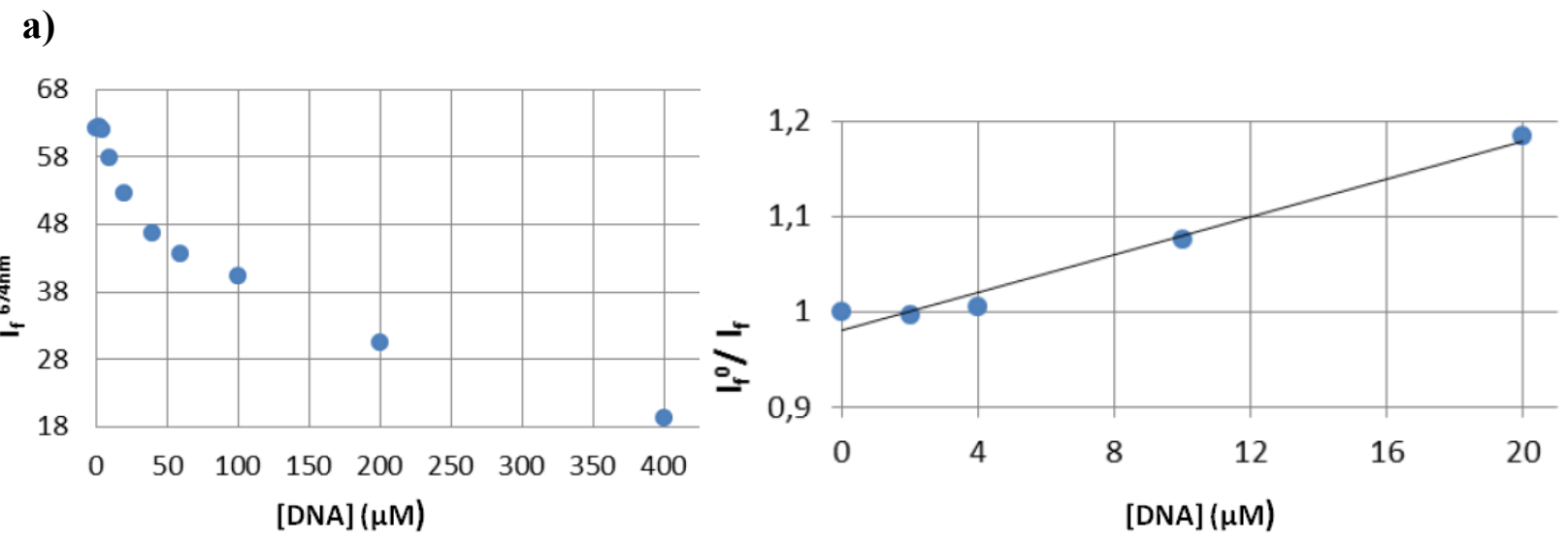

b)
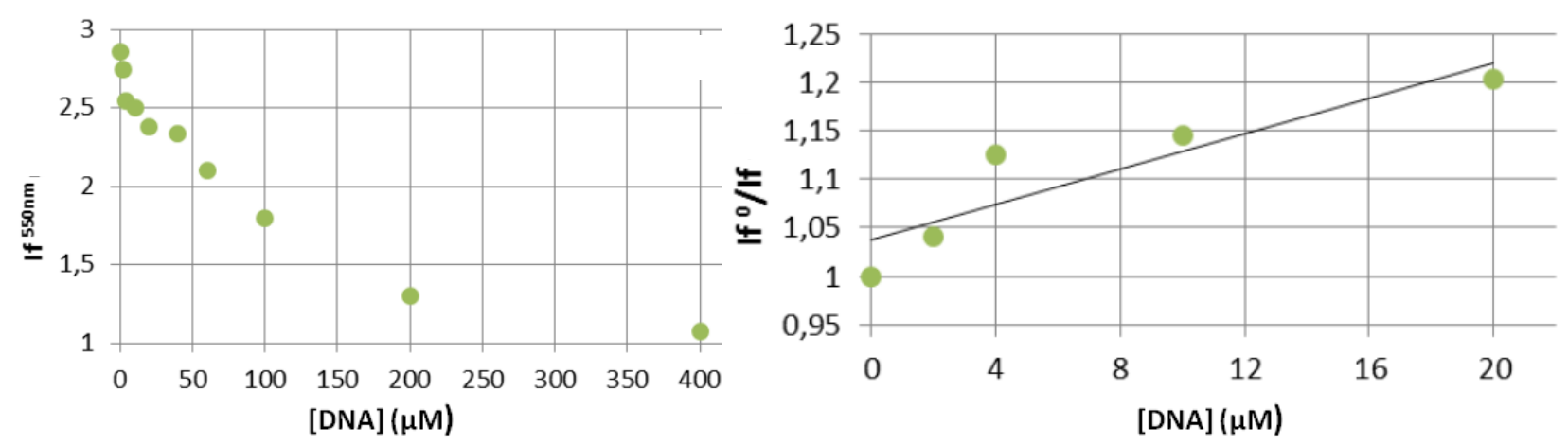

Figure S3. Stern-Volmer quenching plot (right) from the fluorescence data with increasing concentrations of DNA in PBS (left). a) For toluene blue (reference compound). b) For PDO 7. 
a)

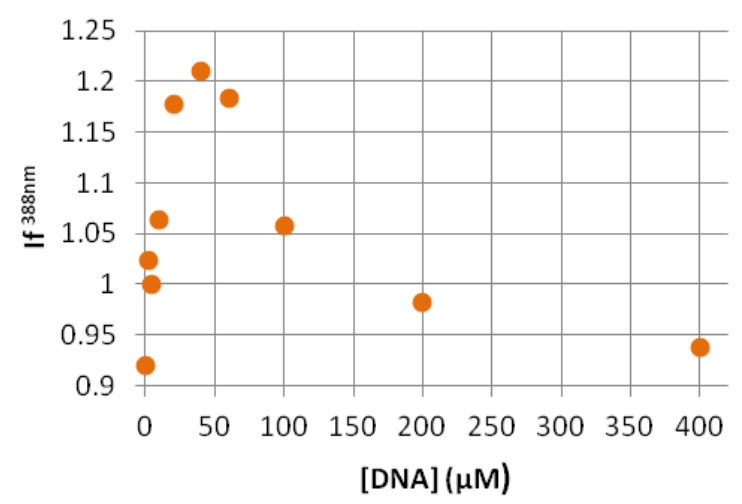

b)

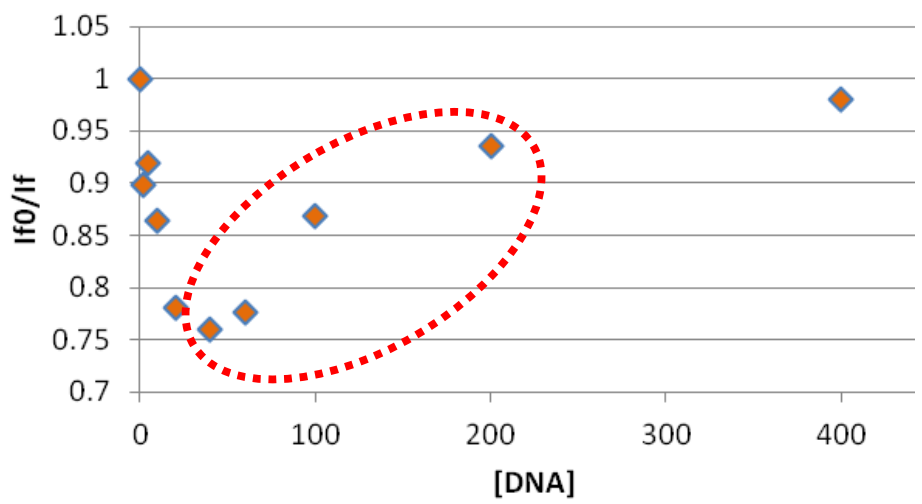

c)

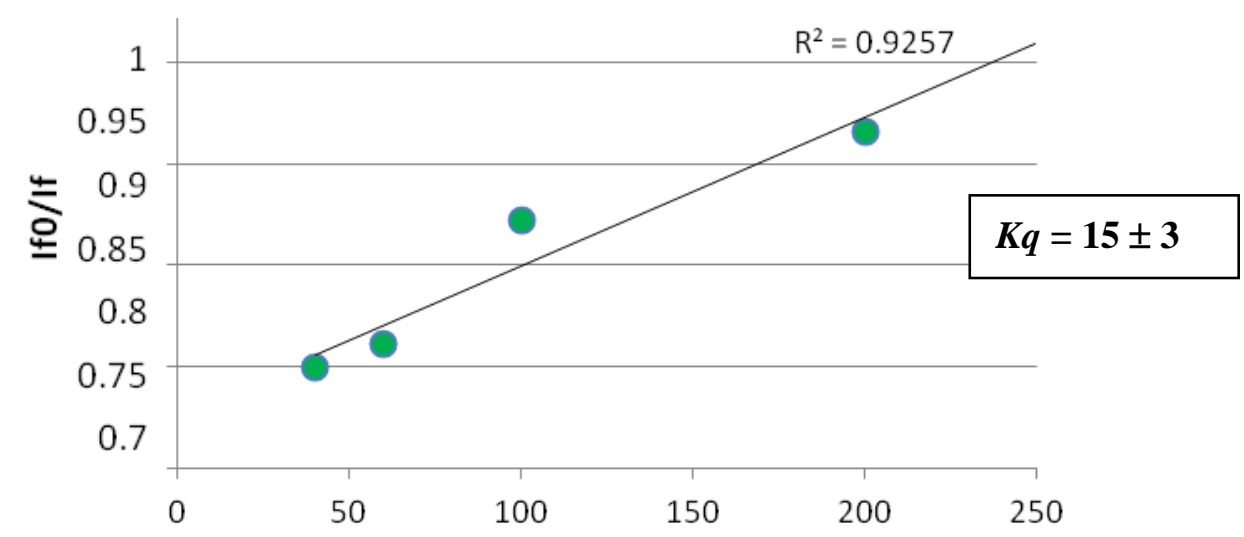

Figure S4. a) Variation of fluorescence of PDO 6 with increasing concentrations of DNA. b) Stern-Volmer quenching plot from the fluorescence data with increasing concentrations of DNA in PBS for PDO 6. The red circle point to the region used to determine the $K p(\mathbf{c}))$. c) $K p$ determination for PDO 6 in the DNA concentrations range 40-200 $\mu \mathrm{M}$. 


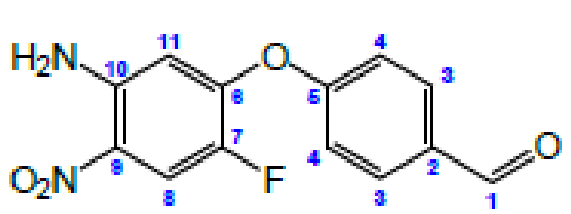

Synthesis of 4-(5-amino-2-fluoro-4nitrophenoxy)benzaldehyde. Dried molecular sieves (3 $\AA$ ) were loaded into the main chamber of a Soxhlet extractor equipment. Then the extractor was placed onto a flask containing a mixture of 4,5-difluoro-2-nitroaniline $(4.5 \mathrm{mmol}), p$-hydroxybenzaldehyde (4.1 $\mathrm{mmol})$, anhydrous potassium carbonate $(4.1 \mathrm{mmol}), 18$-crown-6 $(4.1 \mathrm{mmol})$ and dried toluene (70 $\mathrm{mL})$. The mixture was heated at reflux during $2.5 \mathrm{~h}$. After that, the toluene was evaporated in vacuo and the residue was dissolved in EtOAc $(50 \mathrm{~mL})$ and washed with an aqueous solution of sodium hydroxide $(10 \%)(3 \times 20 \mathrm{~mL})$. The organic phase was dried over anhydrous $\mathrm{Na}_{2} \mathrm{SO}_{4}$ and evaporated in vacuo. The formed solid corresponded to the desired product. Green solid (91\%). ${ }^{1} \mathbf{H}-$ NMR $\left(\mathrm{CDCl}_{3}+\mathrm{D}_{2} \mathrm{O}, 400 \mathrm{MHz}\right) \delta(\mathrm{ppm}): 10.01\left(1 \mathrm{H}, \mathrm{s}, \mathrm{H}_{1}\right), 8.04\left(1 \mathrm{H}, \mathrm{d}, \mathrm{J}=10.8 \mathrm{~Hz}, \mathrm{H}_{8}\right), 7.94(2 \mathrm{H}$, d, J= 8.6 Hz, H $)_{3}, 7.21\left(2 \mathrm{H}, \mathrm{d}, \mathrm{J}=8.6 \mathrm{~Hz}, \mathrm{H}_{4}\right), 6.41\left(1 \mathrm{H}, \mathrm{d}, \mathrm{J}=6.8 \mathrm{~Hz}, \mathrm{H}_{11}\right) .{ }^{13} \mathbf{C}-\mathbf{N M R}\left(\mathrm{CDCl}_{3}, 100\right.$ MHz) $\delta$ (ppm): 191.8, 160.7, 151.0, 146.5, 137.1, 132.6, 130.1, 127.5, 119.1, 114.5, 108.8. MS, $\mathrm{m} / z$ (\%): $276\left(\mathrm{M}^{+}, 100\right), 260\left(\mathrm{M}^{++}-16,2\right), 246\left(\mathrm{M}^{+}-30,10\right), 230\left(\mathrm{M}^{+}-\left[\mathrm{NO}_{2}\right], 10\right)$.

\section{Synthesis of 5-fluoro-6-(4-formylphenoxy)benzo[1,2-}

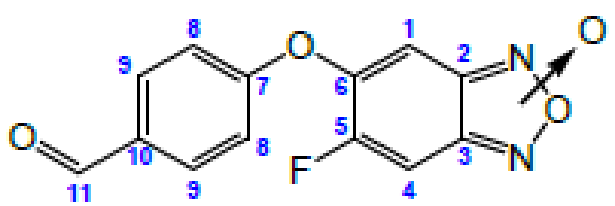

c] $[1,2,5]$ oxadiazole (IV). A solution of 4-(5-Amino-2fluoro-4-nitrophenoxy)benzaldehyde $(4.3 \mathrm{mmol})$ in acetone $(19 \mathrm{~mL})$ and glacial acetic acid $(12 \mathrm{~mL})$ was cooled at $0{ }^{\circ} \mathrm{C}$ and a solution of sodium nitrite $(4.3 \mathrm{mmol})$ in concentrated hydrochloric acid $(1.2$ $\mathrm{mL})$ and water $(3.3 \mathrm{~mL})$ was added dropwise. Then the reaction mixture was stirred during $30 \mathrm{~min}$ at $0{ }^{\circ} \mathrm{C}$. After that, a solution of sodium azide $(4.3 \mathrm{mmol})$ and sodium acetate $(4.3 \mathrm{mmol})$ in water $(1.1 \mathrm{~mL})$ was added dropwise and the reaction mixture was raised to room temperature and stirred for $2 \mathrm{~h}$. The acetone was evaporated in vacuo and the residue was dissolved in EtOAc $(50 \mathrm{~mL})$ and washed with an aqueous solution of sodium hydroxide $(10 \%)(3 \times 20 \mathrm{~mL})$. The organic phase was dried over anhydrous $\mathrm{Na}_{2} \mathrm{SO}_{4}$ and evaporated in vacuo. The residue was dissolved in toluene (75 $\mathrm{mL}$ ) and the solution was heated at reflux for $2 \mathrm{~h}$. The toluene was evaporated in vacuo. The residue was purified by chromatography $\left(\mathrm{SiO}_{2}\right.$, petroleum ether:EtOAc, 8:2) yielding the desired product as a yellow solid $(71 \%) .{ }^{1} \mathbf{H}-\mathbf{N M R}\left(\mathrm{CDCl}_{3}, 400 \mathrm{MHz}\right) \delta(\mathrm{ppm}): 10.05\left(1 \mathrm{H}, \mathrm{s}, \mathrm{H}_{11}\right), 8.01(2 \mathrm{H}, \mathrm{d}, \mathrm{J}=9.1$ $\left.\mathrm{Hz}, \mathrm{H}_{9}\right), 7.30\left(2 \mathrm{H}, \mathrm{d}, \mathrm{J}=9.0 \mathrm{~Hz}, \mathrm{H}_{8}\right), 7.45-7.20\left(1 \mathrm{H}, \mathrm{bs}, \mathrm{H}_{1}\right), 7.25-7.05\left(1 \mathrm{H}, \mathrm{bs}, \mathrm{H}_{4}\right) .{ }^{13} \mathbf{C}-\mathbf{N M R}$ $\left(\mathrm{CDCl}_{3}, 100 \mathrm{MHz}\right) \delta(\mathrm{ppm}): 190.7,159.4,159.3,149.0,134.3,132.7,118.9,118.4,113.1 . \mathrm{MS}, \mathrm{m} / z$ (\%):274 ( $\left.\mathrm{M}^{+}, 100\right), 258\left(\mathrm{M}^{+}-[\mathrm{O}], 15\right), 228\left(\mathrm{M}^{+}-\left[\mathrm{NO}_{2}\right], 2\right), 213\left(\mathrm{M}^{++}-\left[\mathrm{N}_{2} \mathrm{O}_{2}\right]-[\mathrm{H}], 85\right)$. 


\section{Selected NMR spectra}

7(8)-Chloro-2-(4-chlorobenzylamino)phenazine 5,10-dioxide (11)

(7:8 isomers ratio, $44: 56)$<smiles></smiles><smiles>Cc1cc2c(cc1NCc1ccc(Cl)cc1)[n+]([O-])c1cc(Cl)c(Cl)cc1[n+]2[O-]</smiles>

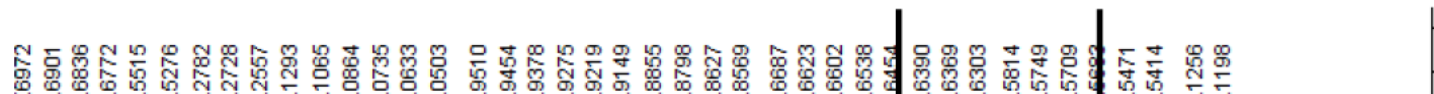

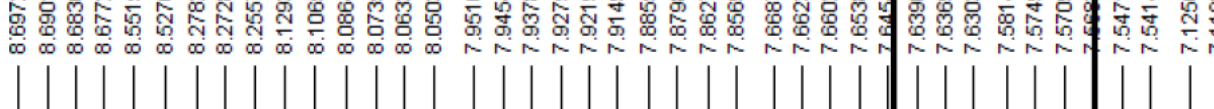
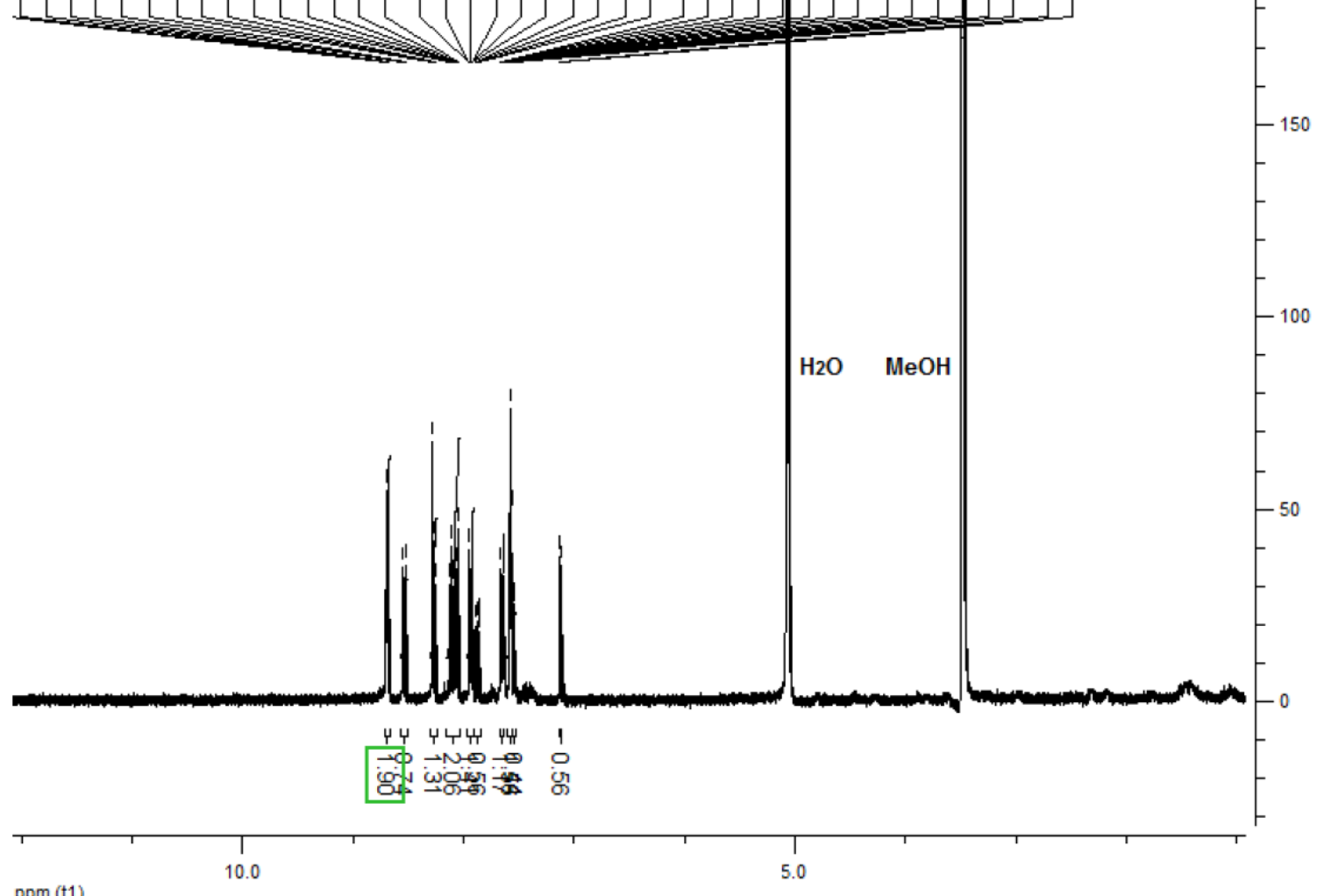

$\mathrm{ppm}(\mathrm{t} 1)$

${ }^{1} \mathrm{H}$ NMR spectrum recorded on a Bruker DPX-400 spectrometer at $298 \mathrm{~K}$ and using $\mathrm{CD}_{3} \mathrm{OD}: \mathrm{D}_{2} \mathrm{O}(9: 1)$ as solvent. 
<smiles></smiles><smiles>[1H]c1cc2c(cc1Cl)[n+]([O-])c1cc(C)c(NCc3ccc(Cl)cc3)cc1[n+]2[O-]</smiles>

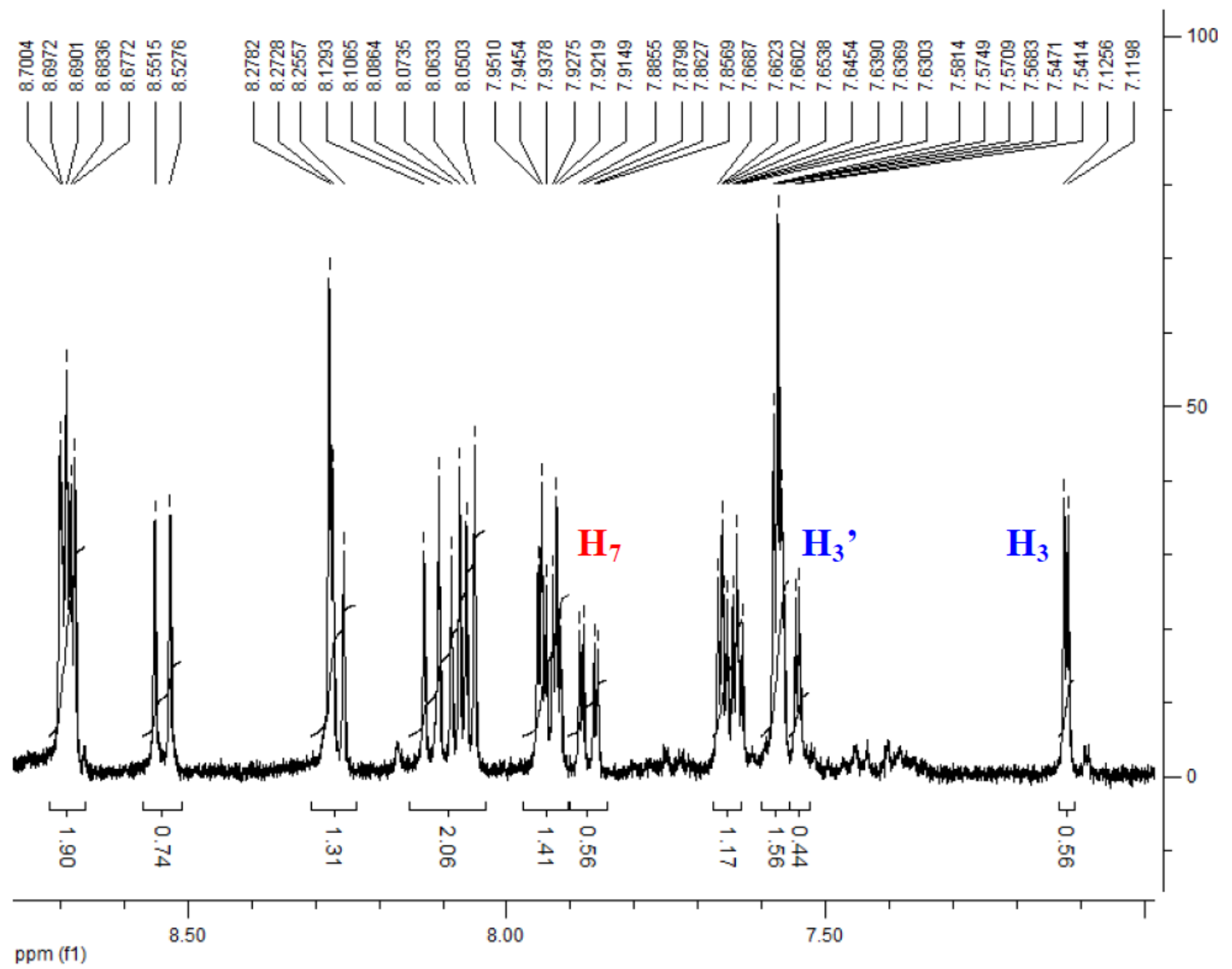

Selected region, aromatics, of the proton NMR spectrum recorded on a Bruker DPX-400 spectrometer at $298 \mathrm{~K}$ and using $\mathrm{CD}_{3} \mathrm{OD}: \mathrm{D}_{2} \mathrm{O}(9: 1)$ as solvent. 
7(8)-Bromo-2-(4-methylphenylsulfonylamino)phenazine 5,10-dioxide (12)

(7:8 isomers ratio, $52: 48$ )

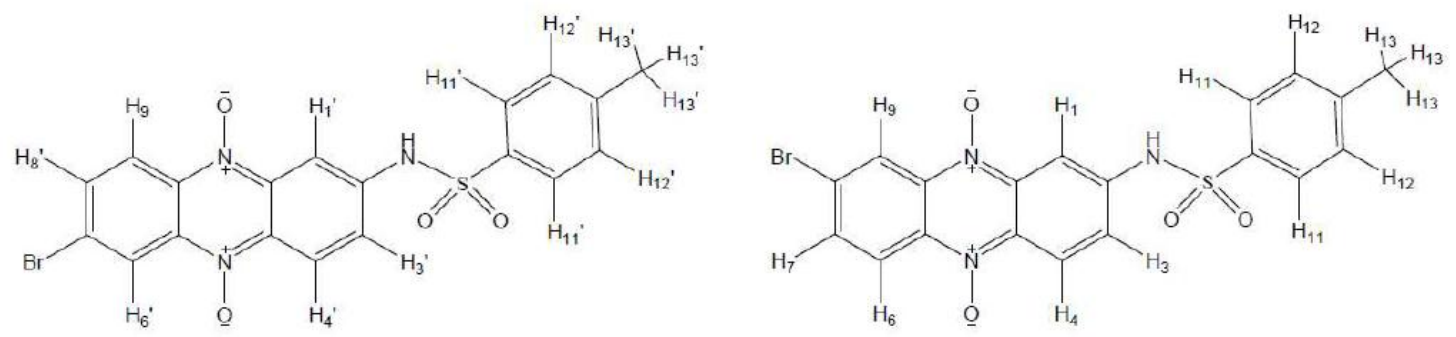

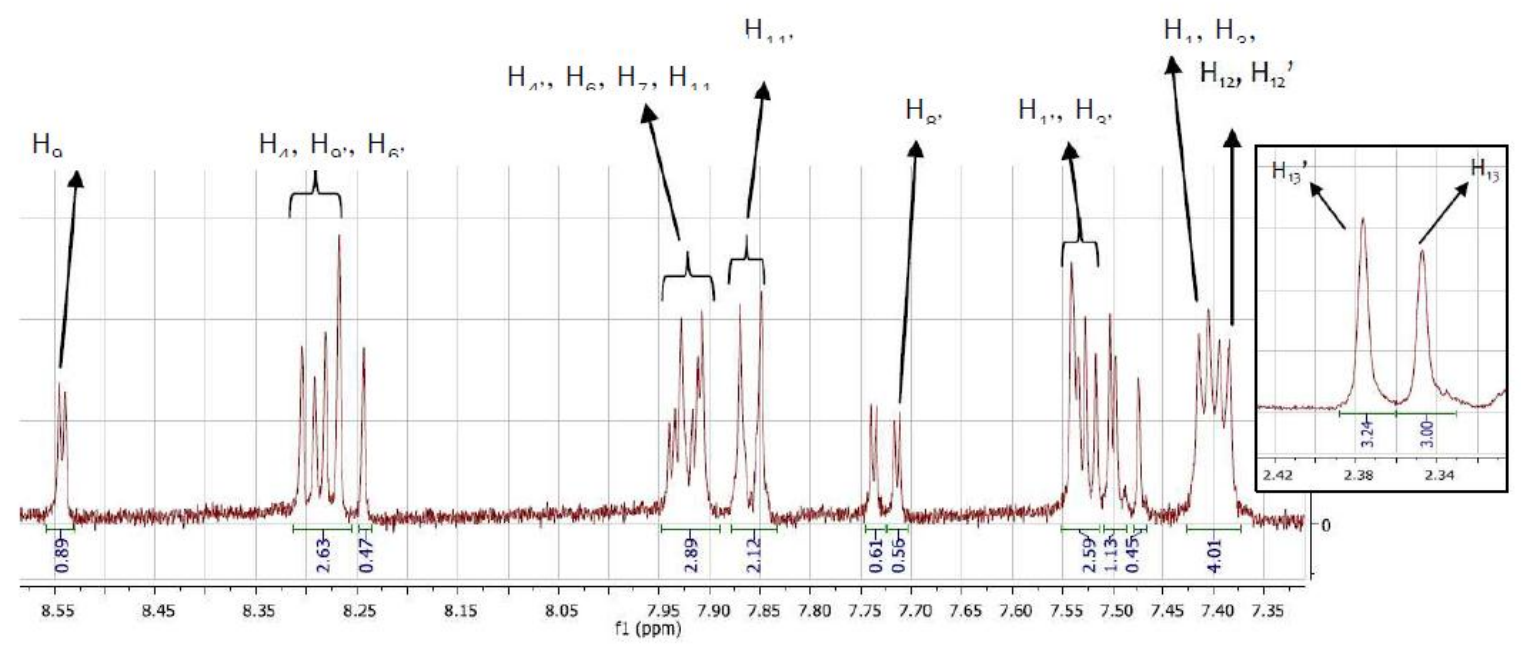

Selected region, aromatics, of the proton NMR spectrum recorded on a Bruker DPX-400 spectrometer at $298 \mathrm{~K}$ and using DMSO- $d_{6}: \mathrm{D}_{2} \mathrm{O}(1: 1)$ as solvent. Inset: region of the methyl-protons. 
2-Amino-7(8)-(E-2-phenylethenyl)phenazine 5,10-dioxide (13)

(7:8 isomers ratio, 65:35)

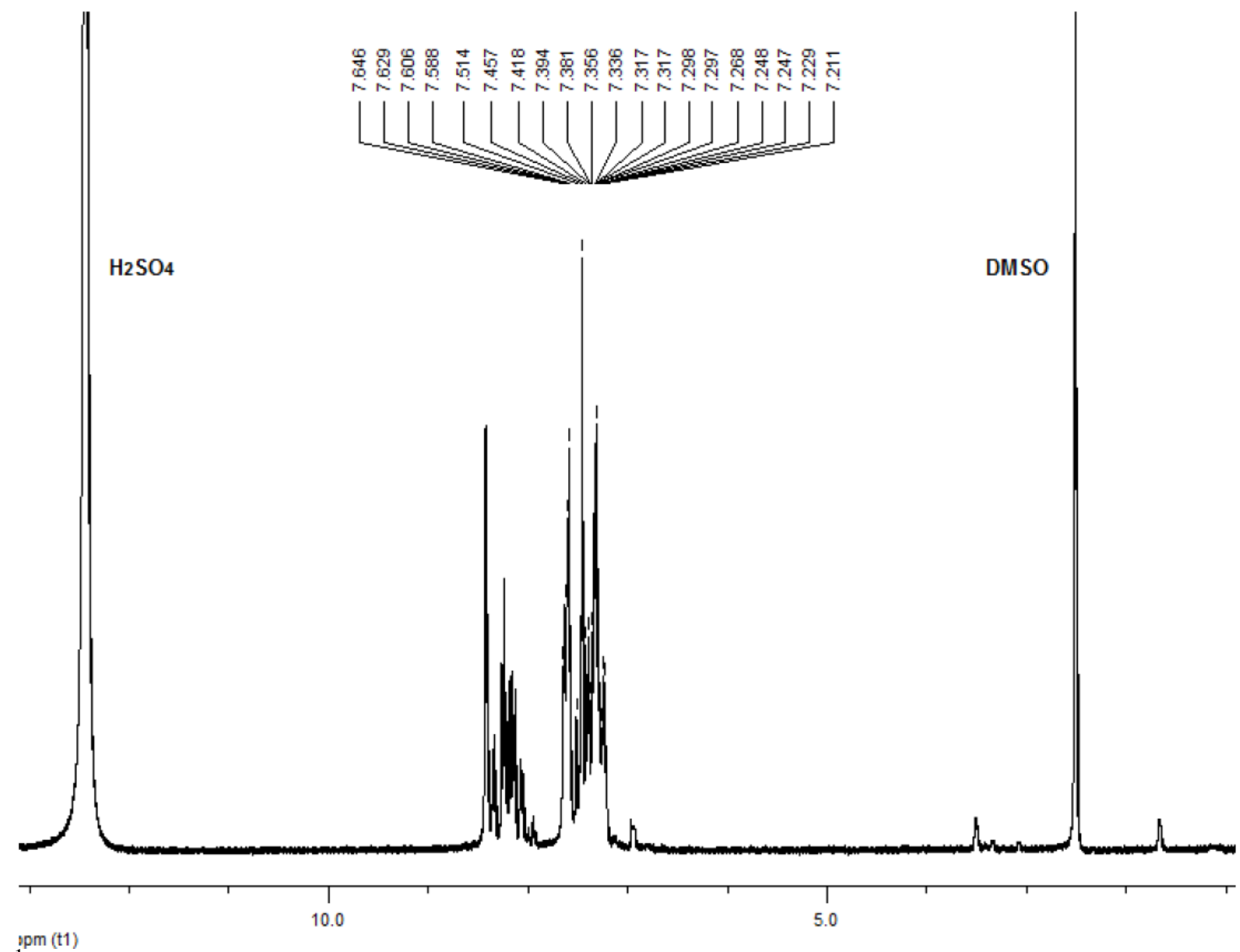

${ }^{1} \mathrm{H}$ NMR spectrum recorded on a Bruker DPX-400 spectrometer at $298 \mathrm{~K}$ and using DMSO- $d_{6}: \mathrm{D}_{2} \mathrm{SO}_{4}(9.5: 0.5)$ as solvent. 

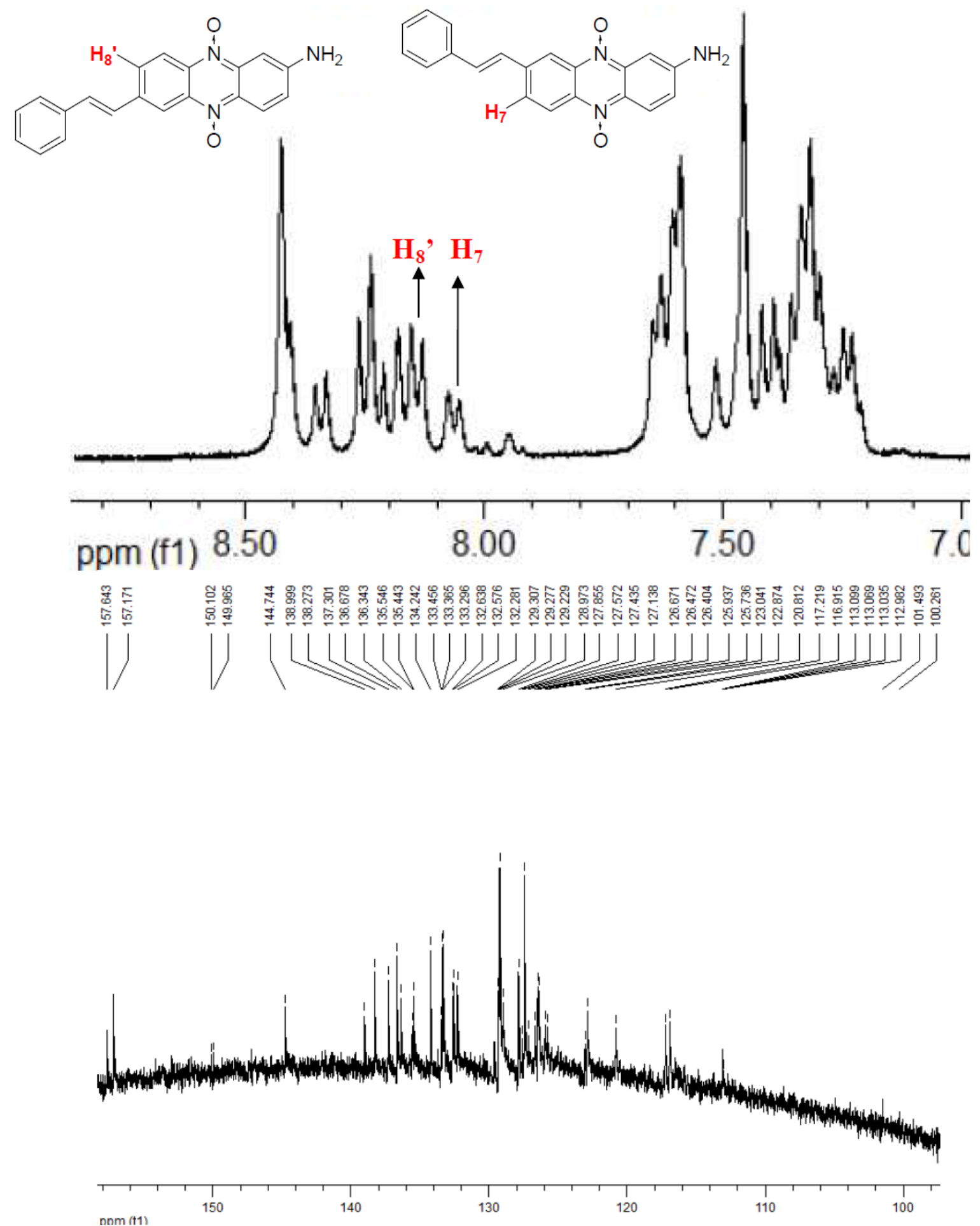

Selected regions, aromatics, of the proton and carbon NMR spectra recorded on a Bruker DPX-400 spectrometer at $298 \mathrm{~K}$ and using DMSO- $d_{6}: \mathrm{D}_{2} \mathrm{SO}_{4}(9.5: 0.5)$ as solvent. 
2-Hydroxy-7(8)-(E-2-phenylethenyl)phenazine 5,10-dioxide (14)

(7:8 isomers ratio, $59: 41)$

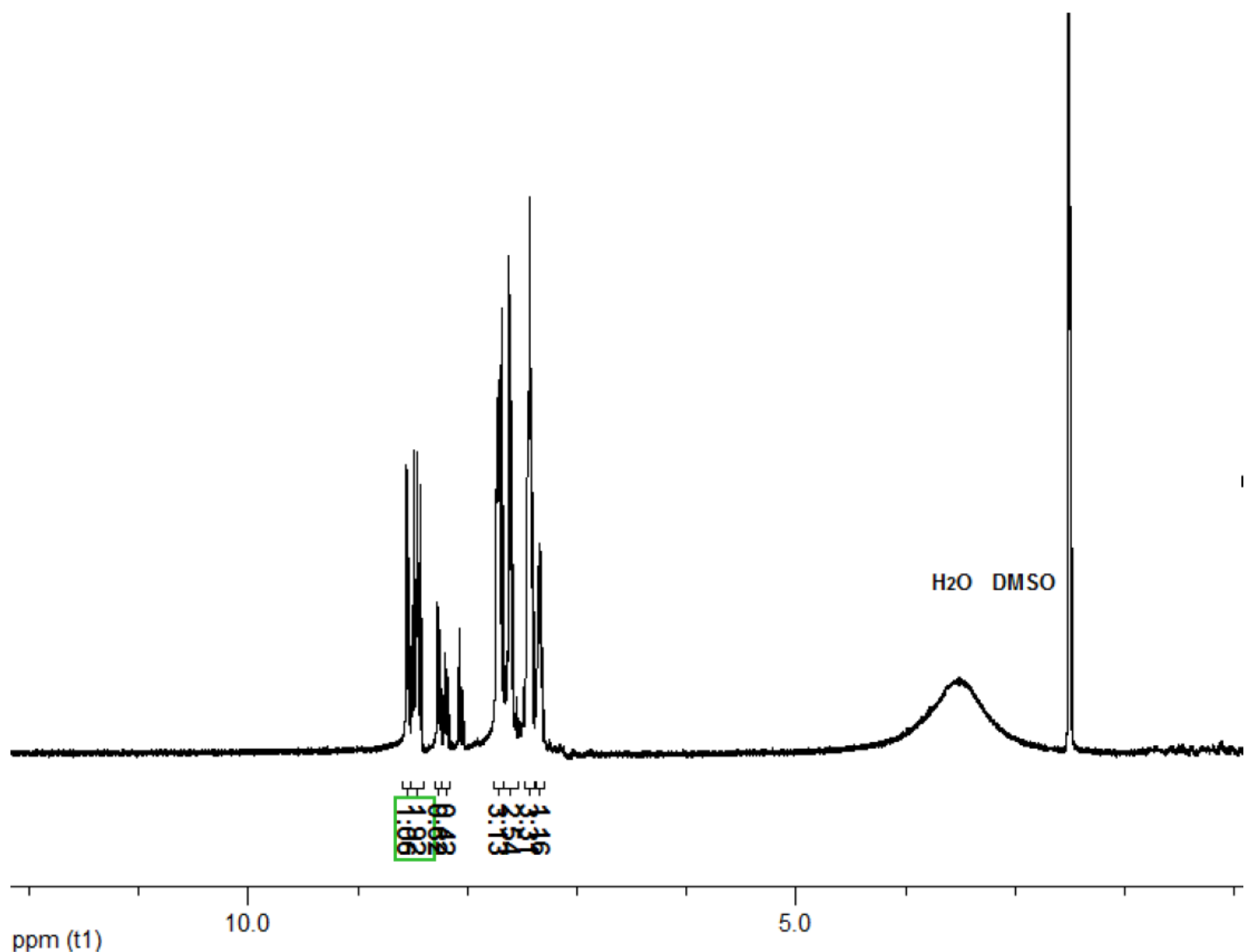

${ }^{1} \mathrm{H}$ NMR spectrum recorded on a Bruker DPX-400 spectrometer at $298 \mathrm{~K}$ and using DMSO- $d_{6}: \mathrm{D}_{2} \mathrm{O}(9.5: 0.5)$ as solvent. 

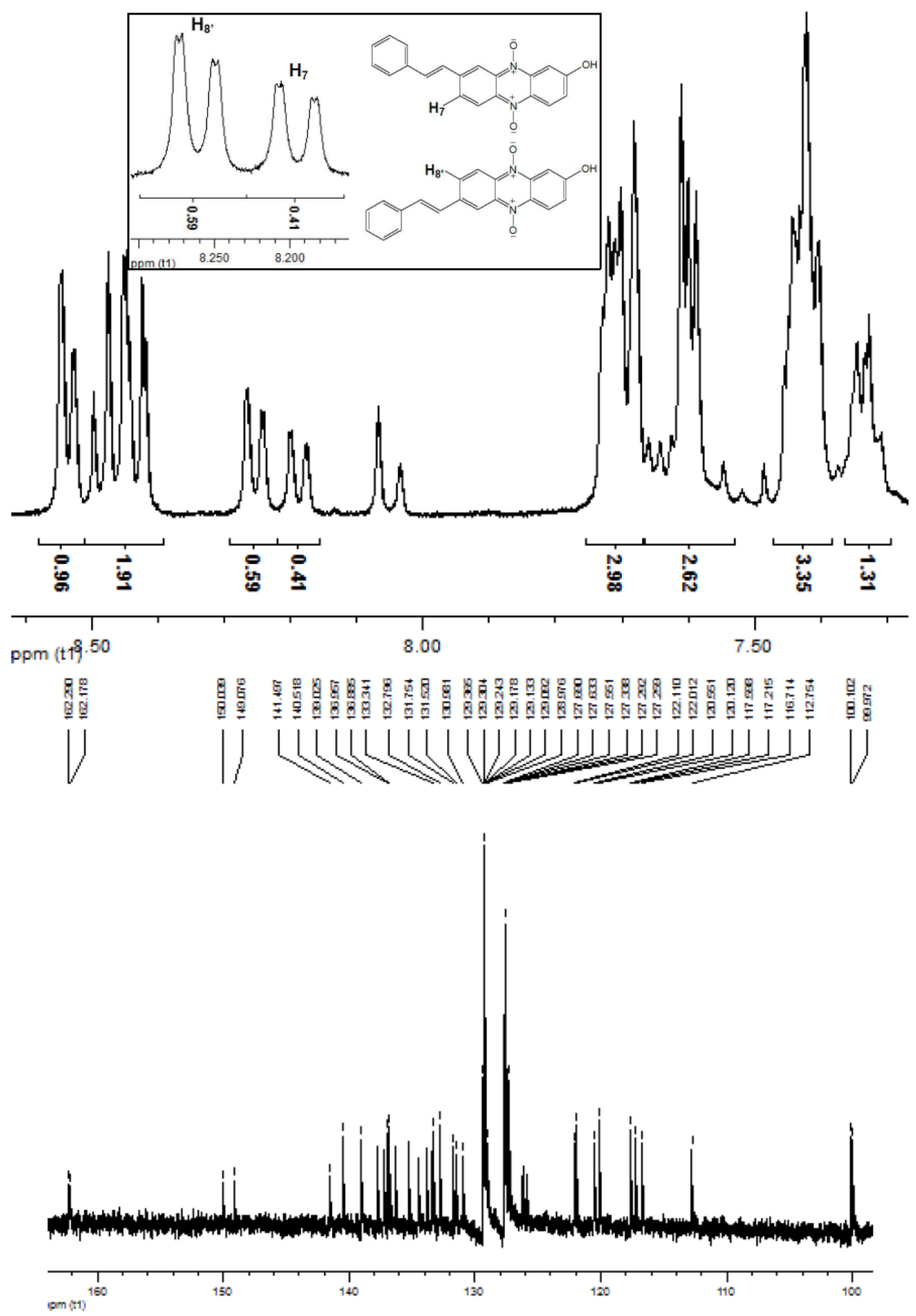

Selected regions, aromatics, of the proton and carbon NMR spectra recorded on a Bruker DPX-400 spectrometer at $298 \mathrm{~K}$ and using DMSO- $d_{6}: \mathrm{D}_{2} \mathrm{O}$ (9.5:0.5) as solvent.. Inset: protons that allowed to determine the ratio of isomers. 
2-Amino-7(8)-[E-2-(4-chlorophenyl)ethenyl)phenazine 5,10-dioxide (15)

(7:8 isomers ratio, $56: 44)$
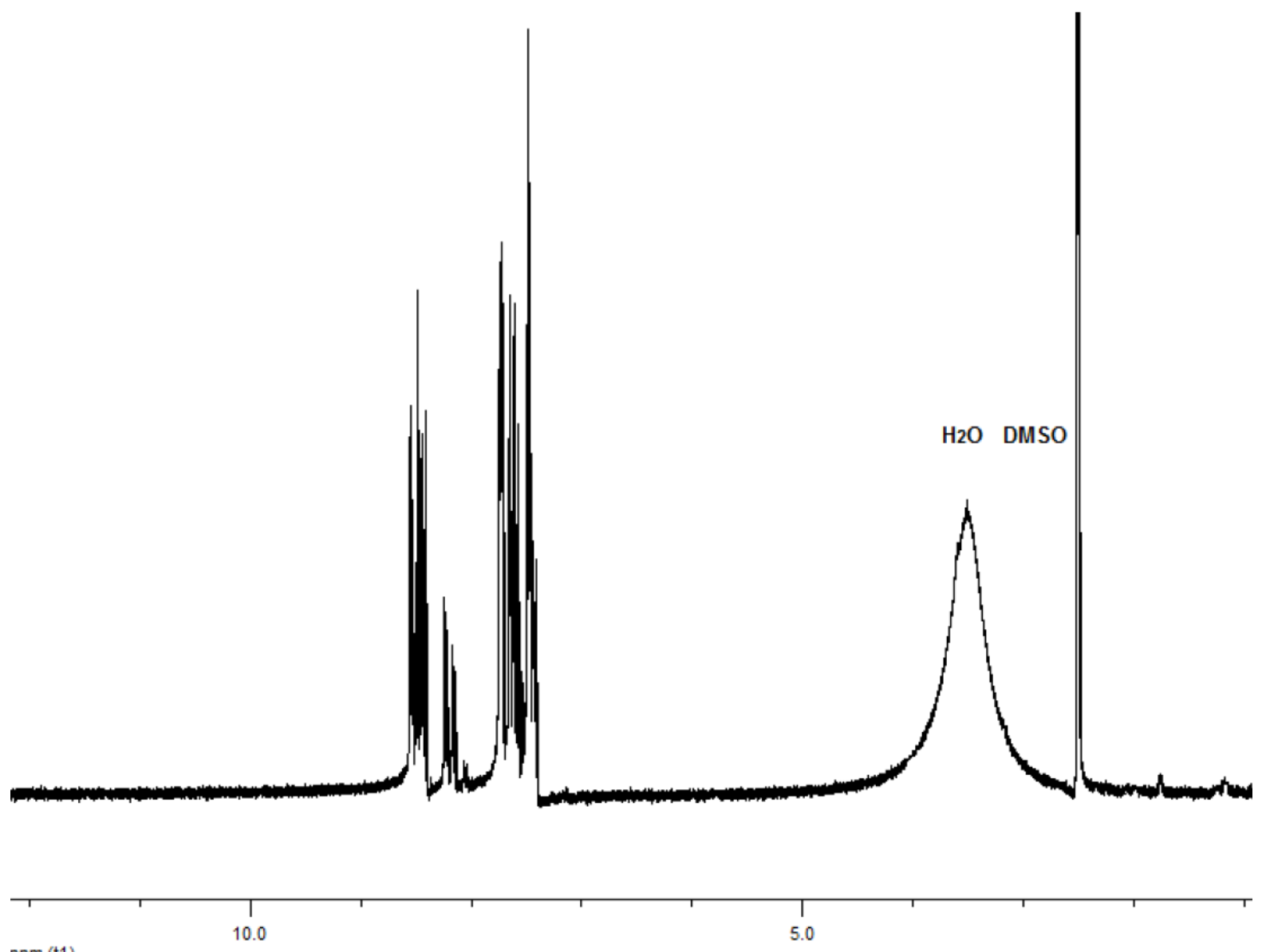

ppm (t1)

${ }^{1} \mathrm{H}$ NMR spectrum recorded on a Bruker DPX-400 spectrometer at $298 \mathrm{~K}$ and using DMSO- $d_{6}: \mathrm{D}_{2} \mathrm{O}(9.5: 0.5)$ as solvent. 
<smiles></smiles><smiles>Nc1ccc2c(c1)[n+]([O-])c1cc(/C=C/c3ccc(Cl)cc3)c([Tl])cc1[n+]2[O-]</smiles><smiles>CC</smiles>
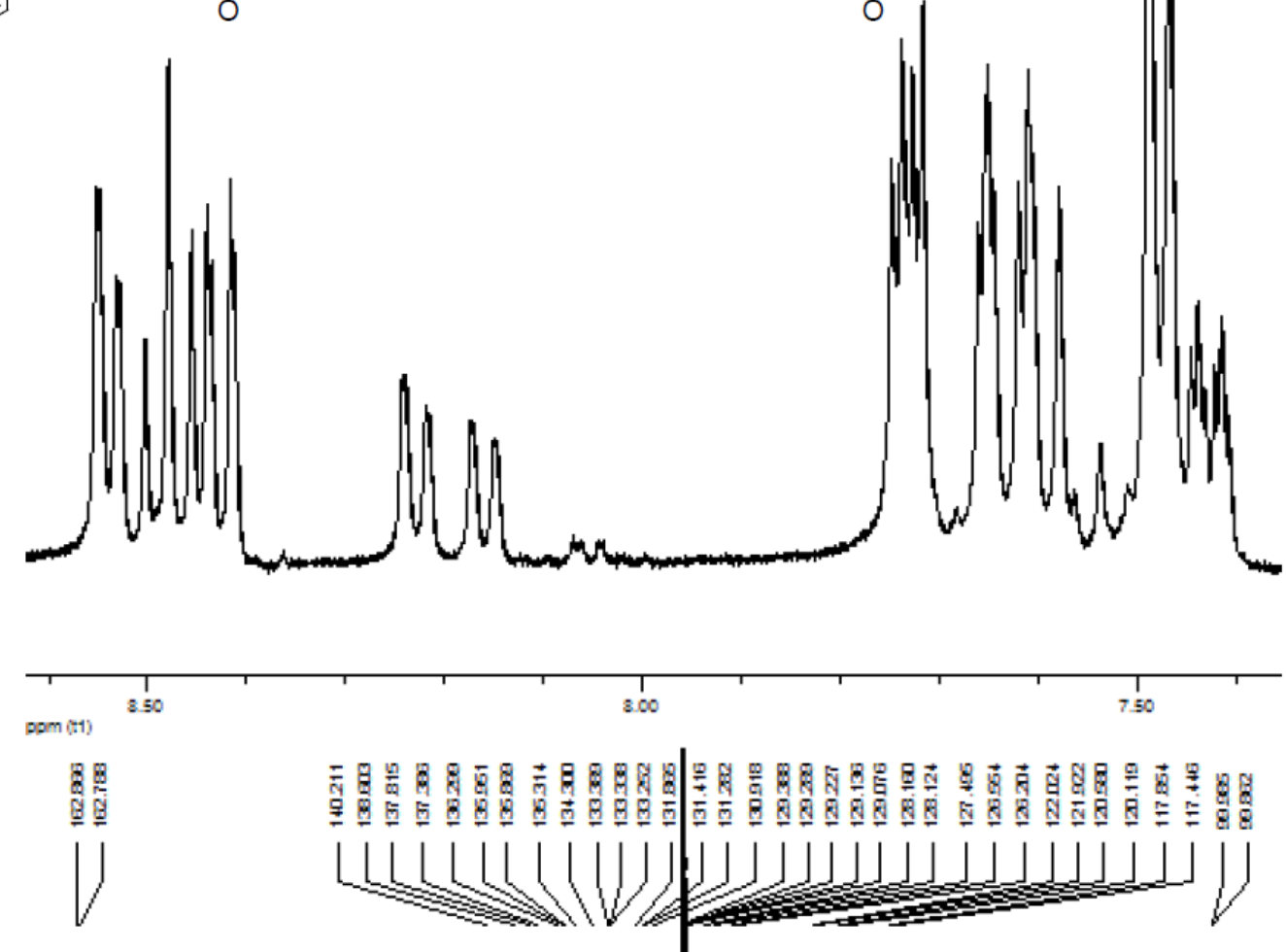

Selected regions, aromatics, of the proton and carbon NMR spectra recorded on a Bruker DPX-400 spectrometer at $298 \mathrm{~K}$ and using DMSO- $d_{6}: \mathrm{D}_{2} \mathrm{O}(9.5: 0.5)$ as solvent. 
(7:8 isomers ratio, $55: 45)$

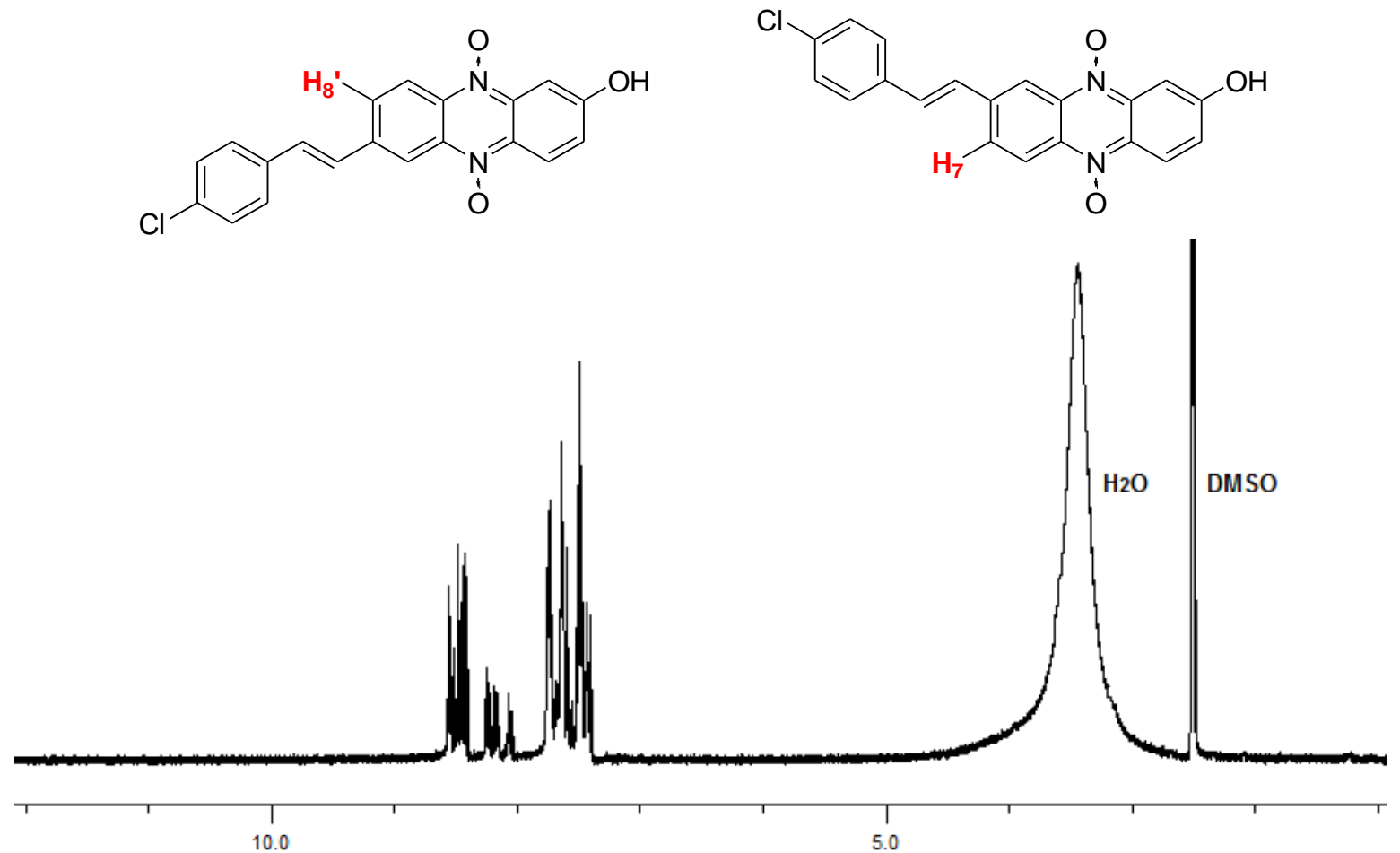

${ }^{\mathrm{p} p m} \mathrm{H}$ NMR spectrum recorded on a Bruker DPX-400 spectrometer at $298 \mathrm{~K}$ and using DMSO- $d_{6}: \mathrm{D}_{2} \mathrm{O}(9.5: 0.5)$ as solvent.

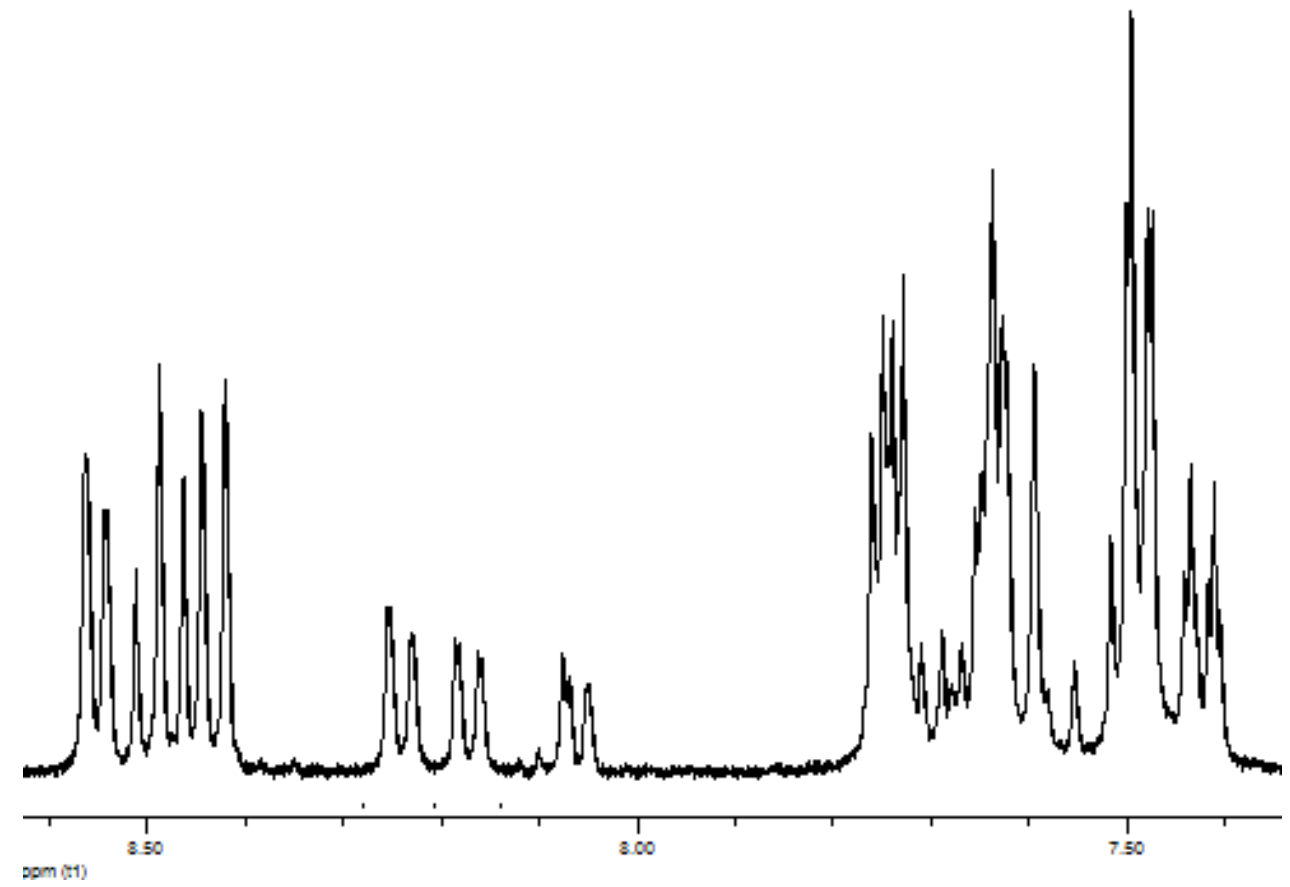

Selected regions, aromatics, of the proton NMR spectrum recorded on a Bruker DPX-400 spectrometer at $298 \mathrm{~K}$ and using DMSO- $d_{6}: \mathrm{D}_{2} \mathrm{O}(9.5: 0.5)$ as solvent. 
(as mixture of aldehyde and the corresponding imine)<smiles></smiles>

19<smiles></smiles>

secondary product

(desired product)

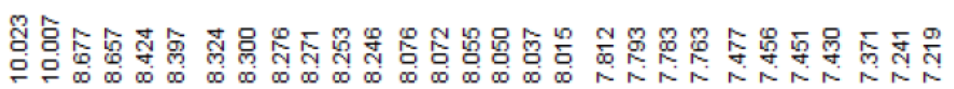
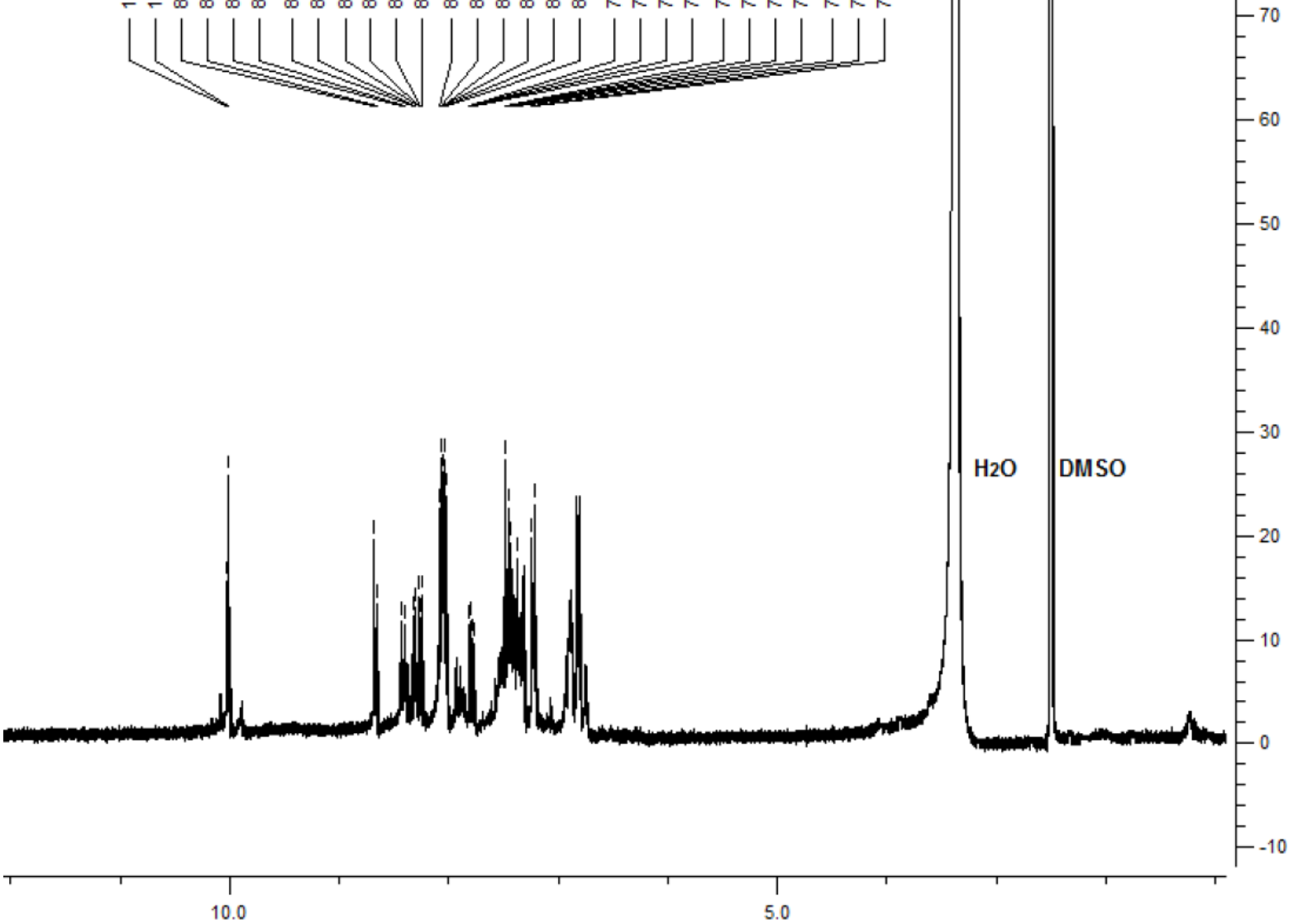

ppm (t1)

${ }^{1} \mathrm{H}$ NMR spectrum recorded on a Bruker DPX-400 spectrometer at $298 \mathrm{~K}$ and using DMSO- $d_{6}: \mathrm{D}_{2} \mathrm{O}(9.5: 0.5)$ as solvent. 


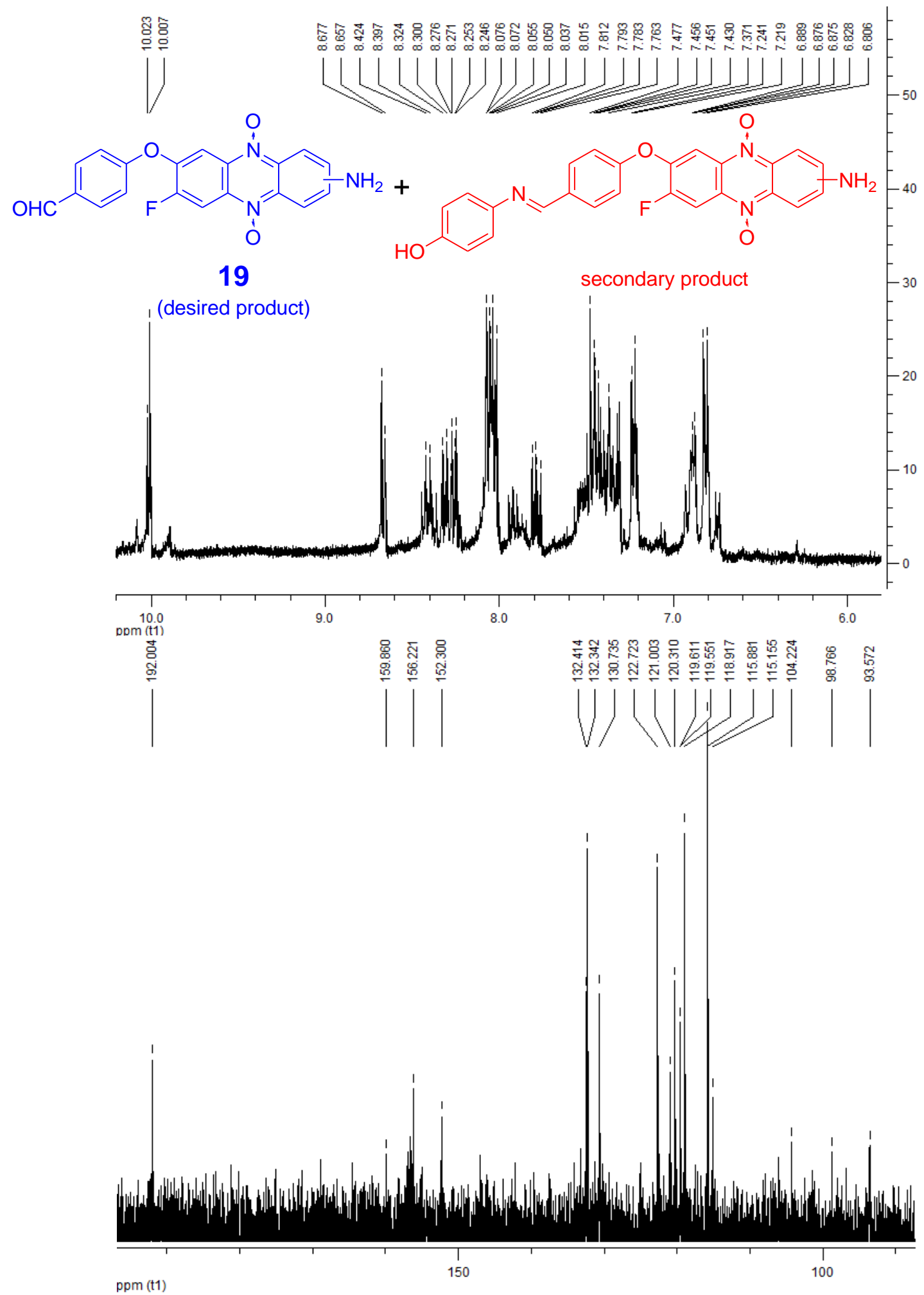

Selected regions, aromatics, of the proton and carbon NMR spectra recorded on a Bruker DPX-400 spectrometer at $298 \mathrm{~K}$ and using DMSO- $d_{6}: \mathrm{D}_{2} \mathrm{O}(9.5: 0.5)$ as solvent. 
7(8)-Fluoro-8(7)-(4-formylphenyloxy)-2-hydroxyphenazine 5,10-dioxide (20)

(7:8 isomers ratio, 65:35)<smiles>O=Cc1ccc(Oc2cc3c(cc2F)[n+]([O-])c2cc(O)ccc2[n+]3[O-])cc1</smiles><smiles>O=Cc1ccc(Oc2cc3c(cc2F)[n+]([O-])c2ccc(O)cc2[n+]3[O-])cc1</smiles>

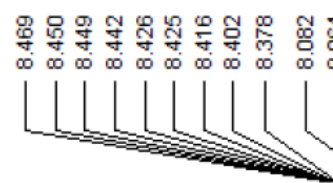

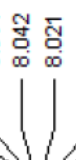

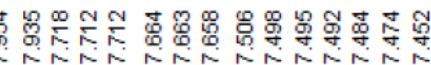
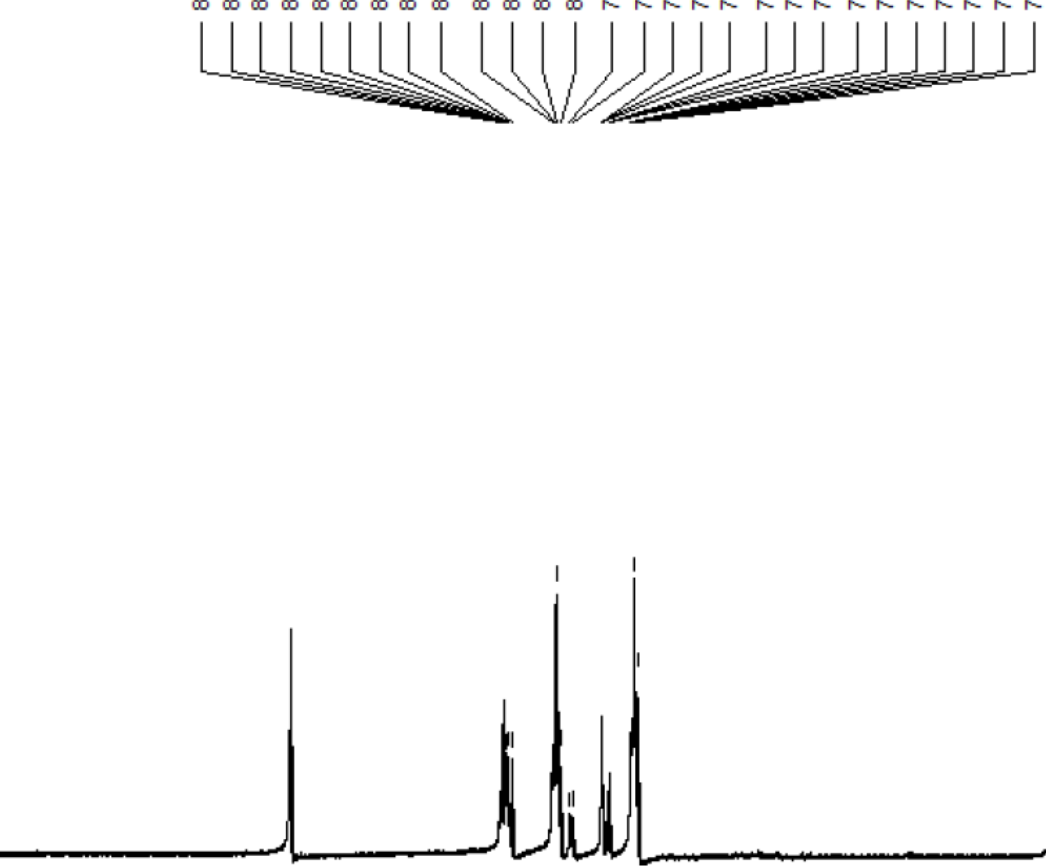

$\mathrm{H} 2 \mathrm{O}$
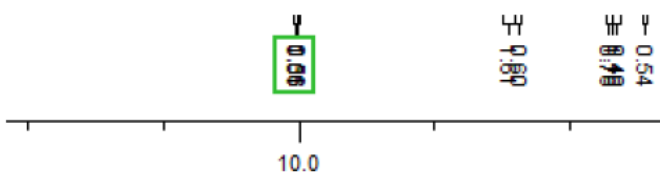

10.0

5.0

${ }^{1} \mathrm{H}$ NMR spectrum recorded on a Bruker DPX-400 spectrometer at $298 \mathrm{~K}$ and using DMSO- $d_{6}: \mathrm{D}_{2} \mathrm{O}(9.5: 0.5)$ as solvent. 

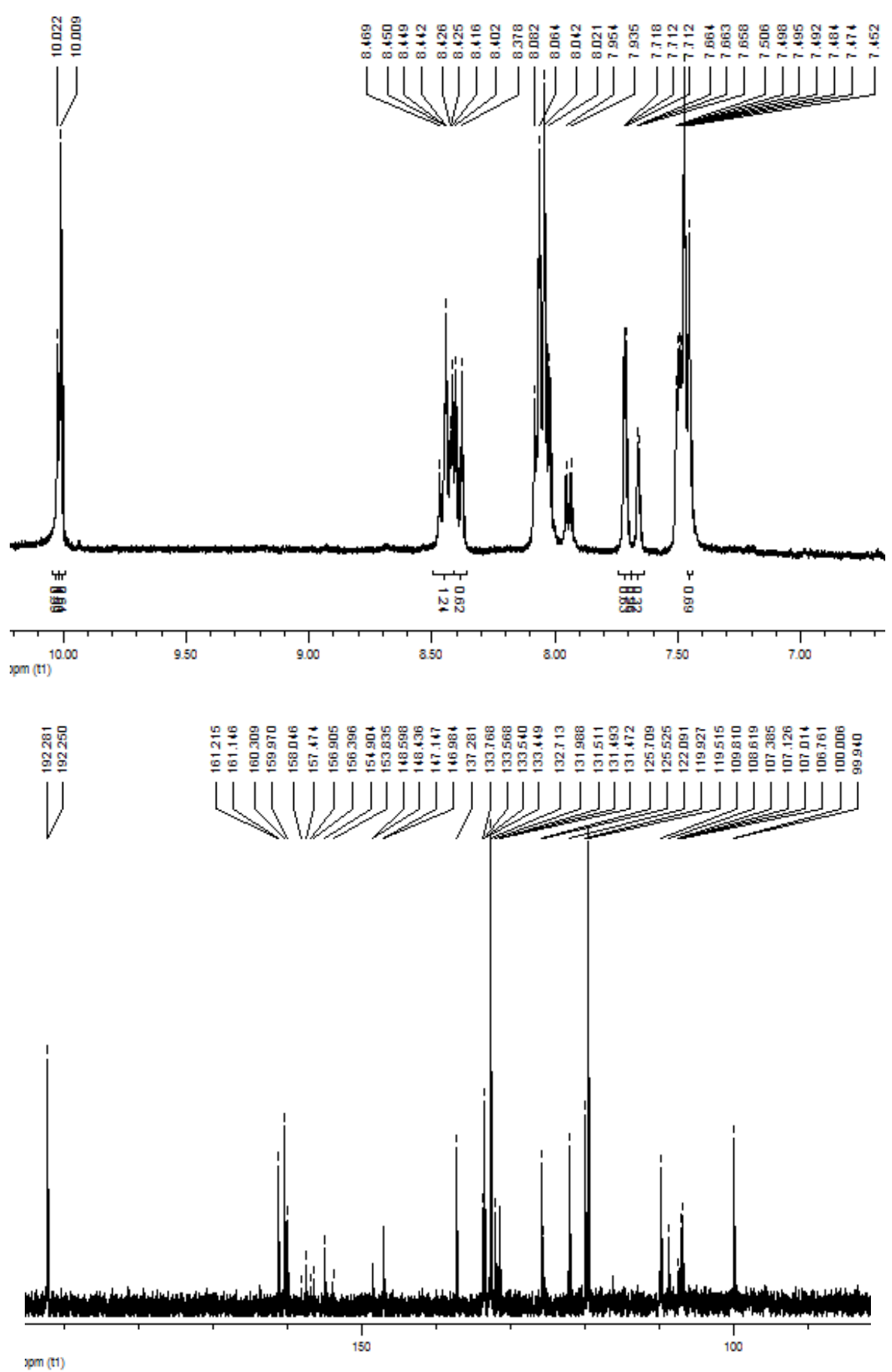

Selected regions, aromatics, of the proton and carbon NMR spectra recorded on a Bruker DPX-400 spectrometer at $298 \mathrm{~K}$ and using DMSO- $d_{6}: \mathrm{D}_{2} \mathrm{O}(9.5: 0.5)$ as solvent. 
(7:8 isomers ratio, $56: 44$ )<smiles></smiles>

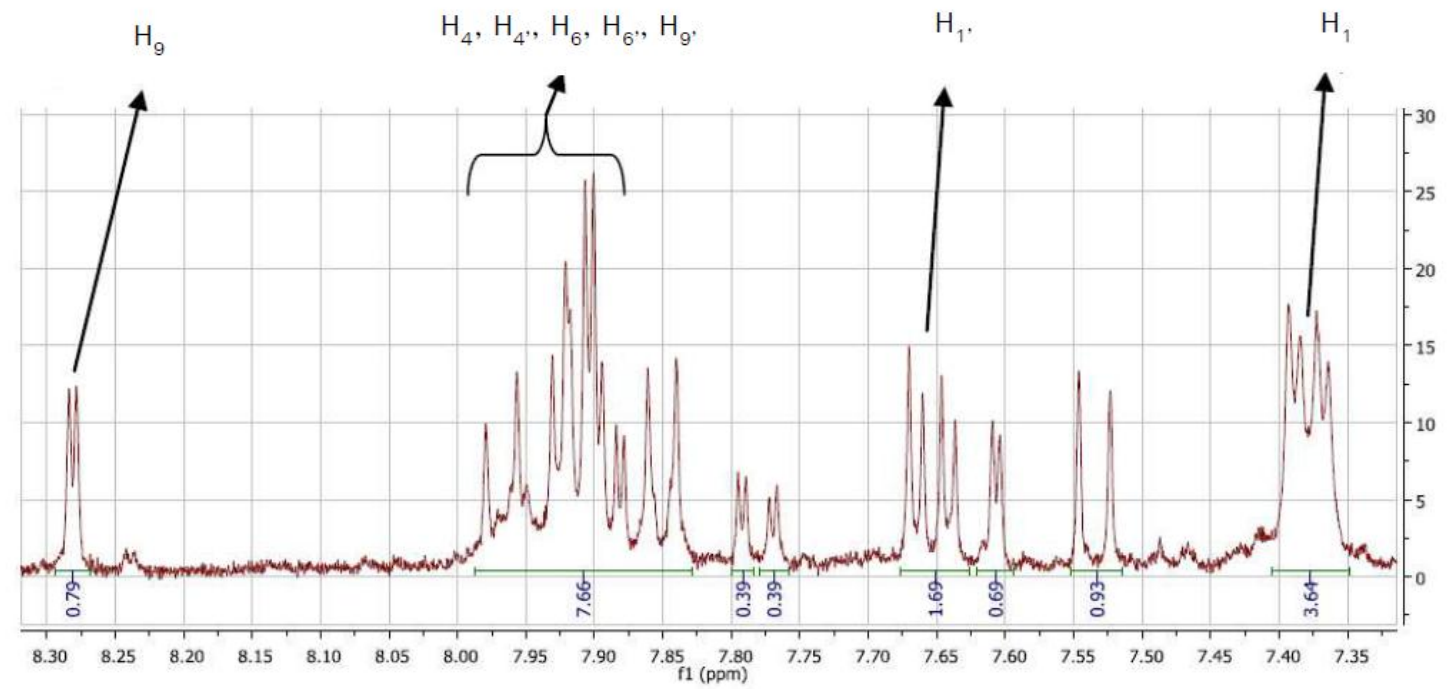

Selected regions, aromatics, of the proton NMR spectrum recorded on a Bruker DPX-400 spectrometer at $298 \mathrm{~K}$ and using DMSO- $d_{6}: \mathrm{D}_{2} \mathrm{O}(1: 1)$ as solvent. 
<smiles>Nc1cc(F)c(Oc2ccc(C=O)cc2)cc1N=C1C=CC=CC1O</smiles>

\section{4}

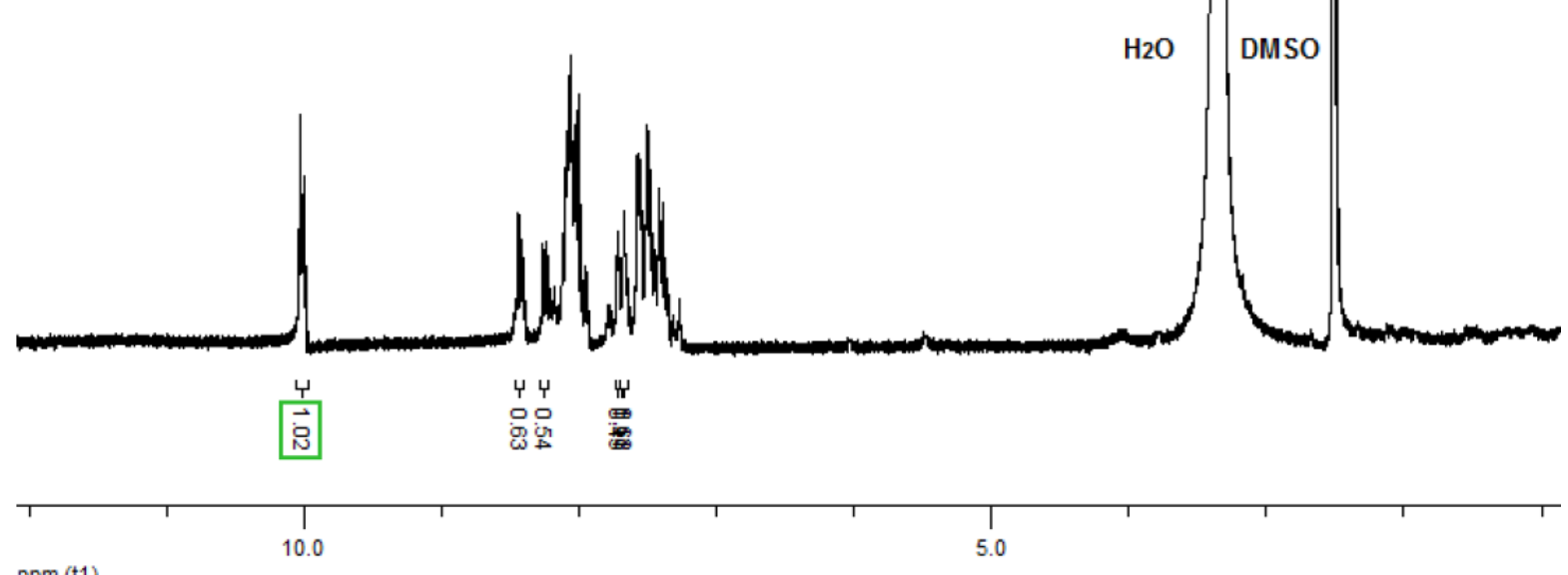

ppm (t1)

${ }^{1} \mathrm{H}$ NMR spectrum recorded on a Bruker DPX-400 spectrometer at $298 \mathrm{~K}$ and using DMSO- $d_{6}: \mathrm{D}_{2} \mathrm{O}(9.5: 0.5)$ as solvent. 


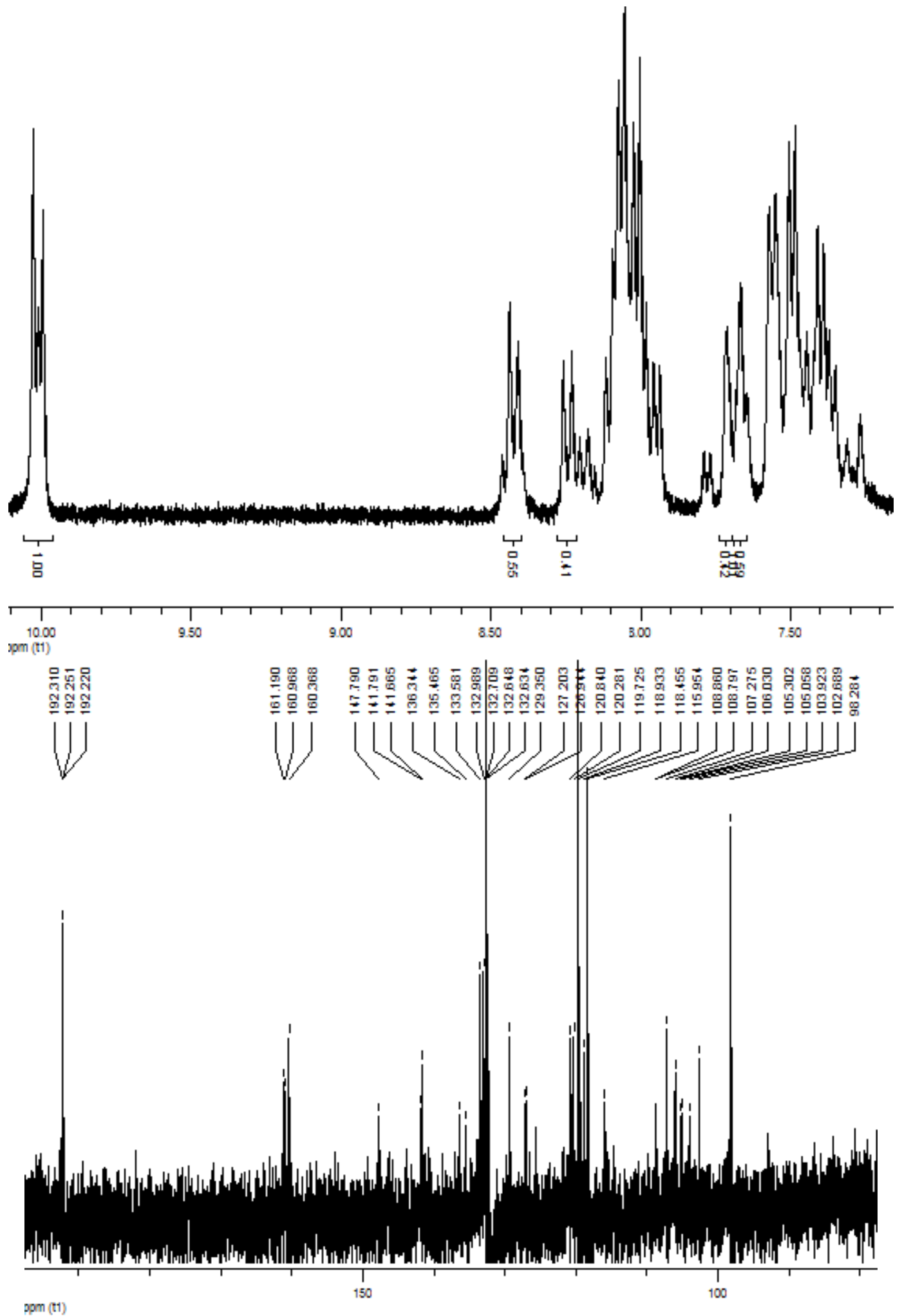

Selected regions, aromatics, of the proton and carbon NMR spectra recorded on a Bruker DPX-400 spectrometer at $298 \mathrm{~K}$ and using DMSO- $d_{6}: \mathrm{D}_{2} \mathrm{O}(9.5: 0.5)$ as solvent. 
(7:8 isomers ratio, $50: 50)$<smiles>O=Cc1ccc(Oc2cc3nc4cc(O)ccc4nc3cc2F)cc1</smiles>

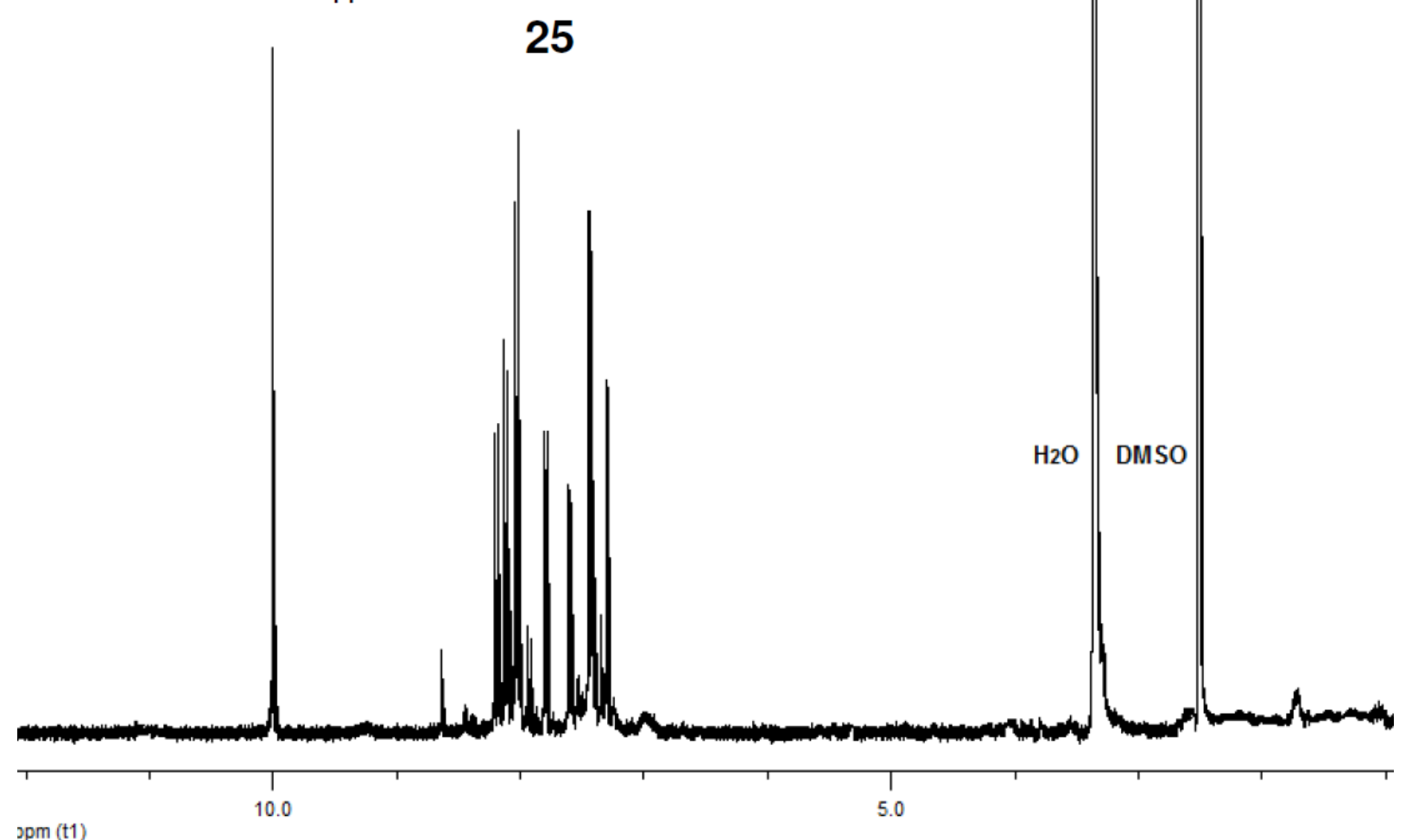

${ }^{1} \mathrm{H}$ NMR spectrum recorded on a Bruker DPX-400 spectrometer at $298 \mathrm{~K}$ and using DMSO- $d_{6}: \mathrm{D}_{2} \mathrm{O}(9.5: 0.5)$ as solvent. 

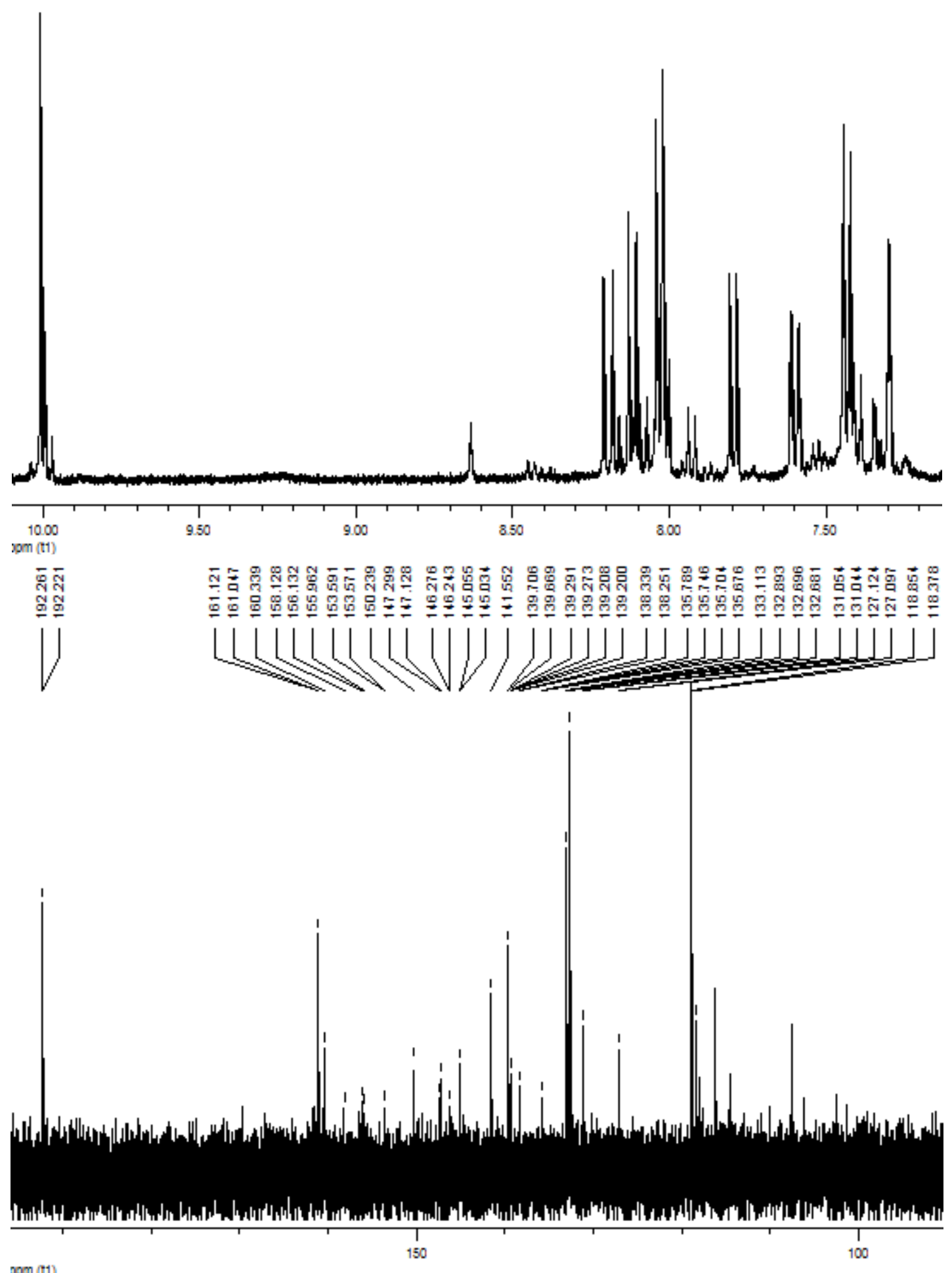

Selected regions, aromatics, of the proton and carbon NMR spectra recorded on a Bruker DPX-400 spectrometer at $298 \mathrm{~K}$ and using DMSO- $d_{6}: \mathrm{D}_{2} \mathrm{O}(9.5: 0.5)$ as solvent. 